\title{
Highly Efficient One-pot Synthesis, Antimicrobial and Docking Studies of Newer $\beta$-amino Carbonyl Derivatives Catalyzed by Silica Sulfuric Acid
}

\author{
Kh. A. M. El-Bayouki, ${ }^{a, *}$ W. M. Basyouni, ${ }^{a}$ A. S. El-Sayed, ${ }^{b}$ W. M. Tohamy, ${ }^{a}$ and A. A. El-Henawy \\ ${ }^{a}$ Organometallic and Organometalloid Chemistry Dept., National Research Centre, Dokki, Cairo, Egypt \\ ${ }^{\mathrm{b}}$ Chemistry Dept. Faculty of Science, Al-Azhar University, Cairo, Egypt
}

RECEIVED OCTOBER 9, 2011; REVISED APRIL 12, 2012; ACCEPTED APRIL 24, 2012

\begin{abstract}
Mannich reaction was applied between 4-fluorobezaldehyde, selected acetophenone and several anilines, catalyzed by silica sulfuric acid for the synthesis of $\beta$-amino carbonyl derivatives. Reaction time and yield of the products depended on the nature of acetophenone and aniline subsituents. Using aliphatic amines instead of aromatic amines under same reaction conditions, afforded aldol condensation products without yielding the expected $\beta$-amino ketones. Replacing the acetophenone derivatives with rhodanine yielded 5-(4-fluorobenzylidene)-thioxothiazolidin-4-one. Using 2-aminothiophenol instead of the aniline derivatives, 2-(4-fluorophenyl)benzothiazole was obtained without isolation of the expected (mercaptophenylamino)-1-(4-substitutedphenyl)propan-1-ones. A proposed reaction mechanism was suggested. Docking studies were designed to gain clear picture of the high active compound(s). A model of high active molecules was mapped for the antimicrobial screening and compared with least active compound(s). (doi: $10.5562 /$ cca1983)
\end{abstract}

Keywords: multi-component reaction; Mannich reactions; $\beta$-aminoketones; silica sulfuric acid; docking studies

\section{INTRODUCTION}

Fluorine has been reported to exert many pronounced effects on the properties of organic compounds when employed as a substituent. As a result, in many areas of applied organic chemistry, including polymer chemistry and biological or medicinal chemistry, fluorinated compounds are attractive synthetic targets and the effects of fluorination on structure-activity relationships received much scrutiny. ${ }^{1}$ Moreover, owing to the growing applications of fluorinated molecules in agro- and pharmaceutical chemistry, several groups have proposed new multifunctional fluorinated synthons, which are very useful as building blocks. ${ }^{2}$ For example, the initial biological studies of a new 2'-deoxy-2'-fluoro-2'-C-methyl nucleoside analogue that was designed and synthesized indicated that this compound showed promising activity against hepatitis $\mathrm{C}$ virus (HCV) replication. ${ }^{3}$

Three-component coupling Mannich reactions are among the most important carbon-carbon bond forming reactions in organic synthesis. ${ }^{4}$ These reactions provided $\beta$-amino carbonyl compounds, which are important synthetic intermediates for various pharmaceuticals and natural products. ${ }^{5}$ Therefore, the development of new synthetic methods leading to $\beta$-amino carbonyl com- pounds has attracted much attention. Due to the limited applications of the classic Mannich reaction, numerous versions of this reaction were developed using performed electrophiles, such as imines and stable nucleophiles, enolates, enol ethers, and enamines. ${ }^{6}$ Hence, there is high interest in developing convenient methods for the synthesis of $\beta$-amino ketone nucleus. Some of these achievements in the efficient construction of this nucleus included the development of Lewis acid catalysts; however, few useful Lewis acid catalysts were developed in the past years. ${ }^{7}$ Also, several one-pot procedures on the use of unmodified aldehydes or ketones were reported with a variety of catalysts such as SDA$\mathrm{HCl},{ }^{8-10} \mathrm{PS}^{-} \mathrm{SO}_{3} \mathrm{H},{ }^{11}$ and chiral Brønsted acid. ${ }^{12,13}$

Silica sulfuric acid (SSA) was introduced as a solid inorganic acidic proton source catalyst ${ }^{14}$ by the reaction of silica-gel and chlorosulfonic acid for the various functional group transformations. ${ }^{15-22}$ In addition, many novel heterogenized catalysts were based on silica supports such as silica sulfuric acid (SSA) due to their high surface areas and porosities, excellent stabilities (chemical and thermal), and facile functionalization with organic groups that can be robustly anchored to the surface. ${ }^{23-25}$

Therefore, the present work is intended for applying a facile and efficient one-pot three-component reac-

\footnotetext{
* Author to whom correspondence should be addressed. (E-mail: khelbayouki@yahoo.com)
} 
tion between 4-fluorobenzaldehyde, selected acetophenone derivatives and several aniline, catalyzed by silica sulfuric acid (SSA) via Mannich reaction in order to synthesize new $\beta$-amino carbonyl compounds (4) with potential biological activity.

\section{CHEMISTRY}

\section{Experimental}

Melting points are uncorrected. Microanalyses were carried out by the Micro-analytical Laboratory, National Research Center, Cairo, Egypt. Infrared spectra (KBr) were recorded using a Jasco FT/IR-300E spectrophotometer. Analytical TLC was performed with silica-gel GF254 plates (petroleum ether / ethyl acetate (4:1 by volume), and the products were visualized by UV detection. Proton and ${ }^{13} \mathrm{C}-\mathrm{NMR}$ spectra $(500$, or $125 \mathrm{~Hz}$; whenever reported) were recorded in DMSO-d $\mathrm{d}_{6}$. Chemical shifts $(\delta)$ reported in ppm using TMS as internal standard and spin-spin coupling constants $(J)$ were given in $\mathrm{Hz}$. EI-MS spectra were measured on an HP 5988A spectrometer by direct inlet at $70 \mathrm{eV}$.

\section{Synthesis of Compounds (4a-n)}

General Procedure: A mixture of 4-flourobenzaldehyde $(2.0 \mathrm{mmol})$, aniline $(2.0 \mathrm{mmol})$, aromatic ketone $(2.0$ $\mathrm{mmol})$, and SSA (0.11 g, $0.04 \mathrm{~mol} \%$ ) was stirred in EtOH $(5 \mathrm{ml})$ at room temperature for $6-13 \mathrm{~h}$. The reaction was monitored on TLC. After completion of the reaction, $\mathrm{CH}_{2} \mathrm{Cl}_{2}$ was added and the catalyst removed by filtration. The obtained filtrate washed with saturated $\mathrm{NaHCO}_{3}$ (aqueous) and brine, dried over anhydrous $\mathrm{Na}_{2} \mathrm{SO}_{4}$, filtered and evaporated to dryness under reduced pressure. The obtained residue purified by silicagel chromatography to obtain compounds $(\mathbf{4 a}-\mathbf{n})$.

3-(4-Fluorophenyl)-1-phenyl-3-(phenylamino)propan-1one (4a): White solid, yield: $70 \%$, m.p.: $110-112{ }^{\circ} \mathrm{C} .{ }^{26}$ $R_{\mathrm{f}}=0.36$. IR (KBr) $v_{\max } / \mathrm{cm}^{-1}: 3383(\mathrm{NH}), 1667(\mathrm{C}=\mathrm{O})$. ${ }^{1} \mathrm{H}$ NMR (500 MHz, DMSO-d ${ }_{6}$ ) $\delta /$ ppm: 3.33-3.55 (m, $2 \mathrm{H}, \mathrm{COCH}_{2}$ ), 4.60 (b, 1H, NH), 4.96 (t, $J=6.75 \mathrm{~Hz}$, 1H, NCH), 6.40-8.00 (m, 14H, ArH). MS (EI) $m / z(\%)$ $=319\left(\mathrm{M}^{+}, 30.24 \%\right)$. Anal. Calcd. for $\mathrm{C}_{21} \mathrm{H}_{18} \mathrm{FNO}$; MW = 319.37: C, 78.98; H, 5.68; N, 4.39. Found C, 78.75; $\mathrm{H}, 5.79 ; \mathrm{N}, 4.66 \%$.

3-(4-Fluorophenyl)-1-phenyl-3-(4-tolylamino)propan-1one (4b): White solid, yield: $68 \%$, m.p.: $131-132{ }^{\circ} \mathrm{C} .{ }^{27}$ $R_{\mathrm{f}}=0.36$. IR $(\mathrm{KBr}) v_{\max } / \mathrm{cm}^{-1}: 3377(\mathrm{NH}), 1672(\mathrm{C}=\mathrm{O})$. ${ }^{1} \mathrm{H}$ NMR $\left(500 \mathrm{MHz}, \mathrm{DMSO}-\mathrm{d}_{6}\right) \delta / \mathrm{ppm}: 2.45(\mathrm{~m}, 3 \mathrm{H}$, $\left.\mathrm{CH}_{3}\right), 3.28-3.36\left(\mathrm{~m}, 2 \mathrm{H}, \mathrm{COCH}_{2}\right), 4.93(\mathrm{t}, J=6.90 \mathrm{~Hz}$, 1H, NCH), 5.96 (b, 1H, NH), 6.36-7.91 (m, 13H, ArH). MS (EI) $m / z=333\left(\mathrm{M}^{+}, 24.15 \%\right)$. Anal. calcd. for $\mathrm{C}_{22} \mathrm{H}_{20} \mathrm{FNO}$; $\mathrm{MW}=333.40$ : C, 79.26; H, 6.05; F, 5.70; N, 4.20. Found: C, 79.35; H, 6.44; N, $4.70 \%$.
3-(4-Fluorophenyl)-3-(4-fluorophenylamino)-1-

phenylpropan-1-one (4c): White solid, yield: $72 \%$, m.p.: $116-118^{\circ} \mathrm{C} . R_{\mathrm{f}}=0.45$. IR $(\mathrm{KBr}) v_{\max } / \mathrm{cm}^{-1}: 3385$ (NH), $1671(\mathrm{C}=\mathrm{O}) .{ }^{1} \mathrm{H}$ NMR $\left(500 \mathrm{MHz}, \mathrm{DMSO}-\mathrm{d}_{6}\right)$ $\delta /$ ppm: $3.31-3.50\left(\mathrm{~m}, 2 \mathrm{H}, \mathrm{COCH}_{2}\right), 4.46(\mathrm{~s}, 1 \mathrm{H}, \mathrm{NH})$, $4.90(\mathrm{t}, J=6.1 \mathrm{~Hz}, 1 \mathrm{H}, \mathrm{NCH}), 6.40-7.94(\mathrm{~m}, 13 \mathrm{H}$, ArH). ${ }^{13} \mathrm{C}$ NMR (125 MHz, DMSO-d 6 ), $\delta /$ ppm: 197.74 (CO), 162.56, 160.64, 155.77, 153.92, 144.88, 140.43, 137.26, 133.74, 129.23, 129.13, 129.07, 128.57, 115.57, 115.47, $114.14(\mathrm{ArC}, \mathrm{ArCH}), 53.40(\mathrm{CHNH}), 46.95$ $\left(\mathrm{CH}_{2}\right)$. MS (EI) $\mathrm{m} / z=337\left(\mathrm{M}^{+}, 24.83 \%\right)$. Anal. Calcd. for $\mathrm{C}_{21} \mathrm{H}_{17} \mathrm{~F}_{2} \mathrm{NO}$; $(\mathrm{MW}=337.36)$ : $\mathrm{C}, 74.76 ; \mathrm{H}, 5.08 ; \mathrm{F}$, 11.26; N, 4.15. Found: C, 74.96; H, 5.11; N, $4.31 \%$.

3-(4-Chlorophenylamino)-3-(4-fluorophenyl)-1-

phenylpropan-1-one (4d): Pale yellow solid, yield: 72 \%, m.p.: $118-120{ }^{\circ} \mathrm{C} . R_{\mathrm{f}}=0.50$. IR (KBr) $v_{\max } / \mathrm{cm}^{-1}$ : $3367(\mathrm{NH}), 1662(\mathrm{C}=\mathrm{O}) .{ }^{1} \mathrm{H}$ NMR (500 MHz, DMSO$\left.\mathrm{d}_{6}\right) \delta / \mathrm{ppm}: 3.30-3.52\left(\mathrm{~m}, 2 \mathrm{H}, \mathrm{COCH}_{2}\right), 4.45(\mathrm{~b}, 1 \mathrm{H}$, $\mathrm{NH}), 4.95(\mathrm{t}, J=6.1 \mathrm{~Hz}, 1 \mathrm{H}, \mathrm{NCH}), 6.42-7.96(\mathrm{~m}, 13 \mathrm{H}$, ArH). ${ }^{13} \mathrm{C}$ NMR $\left(125 \mathrm{MHz}, \mathrm{DMSO}-\mathrm{d}_{6}\right), \delta / \mathrm{ppm}: 197.55$ (CO), 162.63, 160.70, 147.16, 140.19, 137.22, 133.74, 129.22, 129.00, 128.57, 119.85, 115.69, 115.52, 114.77 (Arc, ArCH), $52.78(\mathrm{CHNH}), 46.86\left(\mathrm{CH}_{2}\right) \mathrm{MS}(\mathrm{EI}) \mathrm{m} / \mathrm{z}$ $=353\left(\mathrm{M}^{+}, 31.80 \%\right)$. Anal. Calcd. for $\mathrm{C}_{21} \mathrm{H}_{17} \mathrm{ClFNO}$; $\mathrm{MW}=353.82$ : C, 71.29; H, 4.84; N, 3.96. Found: C, 71.44; H, 4.99; N, $3.41 \%$.

3-(4-Bromophenylamino)-3-(4-fluorophenyl)-1phenylpropan-1-one (4e): White solid, yield: $70 \%$, m.p.: $131-133{ }^{\circ} \mathrm{C} . R_{\mathrm{f}}=0.55$. IR $(\mathrm{KBr}) v_{\max } / \mathrm{cm}^{-1}: 3365$ (NH), $1662(\mathrm{C}=\mathrm{O}) .{ }^{1} \mathrm{H}$ NMR (500 MHz, DMSO-d 6 ), $\delta /$ ppm: 3.26-3.58 (m, 2H, $\left.\mathrm{COCH}_{2}\right), 4.46(\mathrm{~b}, 1 \mathrm{H}, \mathrm{NH})$, 4.93 (m, 1H, NCH), 6.41-7.93 (m, 13H, ArH). MS (EI) $m / z=398\left(\mathrm{M}^{+}, 15.60 \%\right)$. Anal. Calcd. for $\mathrm{C}_{21} \mathrm{H}_{17} \mathrm{BrFNO}$; $\mathrm{MW}=398.27: \mathrm{C}, 63.33 ; \mathrm{H}, 4.30 ; \mathrm{N}, 3.52$. Found C, 63.56; H, 4.88; N, $3.86 \%$.

3-(4-Fluorophenyl)-3-(phenylamino)-1-4-tolylpropan-1one (4f): White solid, yield: $76 \%$, m.p.: $92-93{ }^{\circ} \mathrm{C} . R_{\mathrm{f}}=$ 0.41. IR (KBr) $v_{\max } / \mathrm{cm}^{-1}: 3369(\mathrm{NH}), 1660(\mathrm{C}=\mathrm{O}) .{ }^{1} \mathrm{H}$ NMR (500 MHz, DMSO-d d $_{6}, \delta /$ ppm: $2.46\left(\mathrm{~s}, 3 \mathrm{H}, \mathrm{CH}_{3}\right)$, 3.30-3.55 (m, 2H, $\left.\mathrm{COCH}_{2}\right), 4.60$ (b, 1H, NH), 5.00 (t, $J$ $=6.4 \mathrm{~Hz}, 1 \mathrm{H}, \mathrm{NCH}), 6.46-8.00(\mathrm{~m}, 13 \mathrm{H}, \mathrm{ArH}) . \mathrm{MS}(\mathrm{EI})$ $m / z=333\left(\mathrm{M}^{+}, 10.22 \%\right)$. Anal. Calcd. for $\mathrm{C}_{22} \mathrm{H}_{20} \mathrm{FNO}$; $\mathrm{MW}=333.40: \mathrm{C}, 79.26 ; \mathrm{H}, 6.05 ; \mathrm{N}, 4.20$. Found: C, $79.11 ; \mathrm{H}, 6.54 ; \mathrm{N}, 4.65 \%$.

3-(4-Fluorophenyl)-1-p-tolyl-3-(4-tolylamino) propan1-one (4g): White solid, yield: $66 \%$, m.p.: $150-152{ }^{\circ} \mathrm{C}$. $R_{\mathrm{f}}=0.39$. IR $(\mathrm{KBr}) v_{\max } / \mathrm{cm}^{-1}: 3357(\mathrm{NH}), 1673(\mathrm{C}=\mathrm{O})$. ${ }^{1} \mathrm{H}$ NMR (500 MHz, DMSO-d ${ }_{6}$ ), $\delta / \mathrm{ppm}: 2.33$ (s, 3H, $\left.\mathrm{CH}_{3}\right), 2.55\left(\mathrm{~s}, 3 \mathrm{H}, \mathrm{CH}_{3}\right), 3.20-3.56\left(\mathrm{~m}, 2 \mathrm{H}, \mathrm{COCH}_{2}\right)$, $4.91(\mathrm{~m}, 1 \mathrm{H}, \mathrm{NCH}), 5.94(\mathrm{~s}, 1 \mathrm{H}, \mathrm{NH}), 6.35-7.82(\mathrm{~m}$, $12 \mathrm{H}, \mathrm{ArH}) .{ }^{13} \mathrm{C}$ NMR $\left(125 \mathrm{MHz}, \mathrm{DMSO}-\mathrm{d}_{6}\right), \delta / \mathrm{ppm}$ : 197.44 (CO), 160.53, 145.86, 144.10, 140.74, 134.81, 129.72, 129.07, 128.71, 124.89, 121.08, 120.24, 115.52, 115.36, 113.63 (ArC, $\mathrm{ArCH}), 53.08(\mathrm{CHNH}), 46.79$ 
$\left(\mathrm{CH}_{2}\right), 21.67\left(\mathrm{CH}_{3}\right), 20.53\left(\mathrm{CH}_{3}\right)$. MS (EI) $\mathrm{m} / z=347$ $\left(\mathrm{M}^{+}, 25.24 \%\right)$. Anal. Calcd. for $\mathrm{C}_{23} \mathrm{H}_{22} \mathrm{FNO}$; $\mathrm{MW}=$ 347.43: C, 79.51; H, 6.38; N, 4.03. Found: C, 79.88; H, $6.80 ; \mathrm{N}, 4.35 \%$.

3-(4-Fluorophenyl)-3-(4-fluorophenylamino)-1-ptolylpropan-1-one (4h): White solid, yield: $66 \%$, m.p.: $128-130{ }^{\circ} \mathrm{C} . R_{\mathrm{f}}=0.53$. IR $(\mathrm{KBr}) v_{\max } / \mathrm{cm}^{-1}: 3362$ $(\mathrm{NH}), 1656(\mathrm{C}=\mathrm{O}) .{ }^{1} \mathrm{H}$ NMR $\left(500 \mathrm{MHz}, \mathrm{DMSO}^{-\mathrm{d}_{6}}\right)$, $\delta / \mathrm{ppm}: 2.34\left(\mathrm{~m}, 3 \mathrm{H}, \mathrm{CH}_{3}\right), 3.30-3.46\left(\mathrm{~m}, 2 \mathrm{H}, \mathrm{COCH}_{2}\right)$, $4.50(\mathrm{~b}, 1 \mathrm{H}, \mathrm{NH}), 4.95(\mathrm{t}, J=6.90 \mathrm{~Hz}, 1 \mathrm{H}, \mathrm{NCH})$, 6.40-7.89 (m, 12H, ArH). MS (EI) $m / z=351\left(\mathrm{M}^{+}\right.$, 20.15). Anal. Calcd. for $\mathrm{C}_{22} \mathrm{H}_{19} \mathrm{~F}_{2} \mathrm{NO} ; \mathrm{MW}=351.39$ : $\mathrm{C}$, 75.20; H, 5.45; N, 3.99. Found: C, 75.42; H, 5.84; N, $3.72 \%$.

\section{1-(4-Chlorophenyl)-3-(4-fluorophenyl)-3-(phenyl-} amino)propan-1-one $(4 i)$ : White solid, yield: $87 \%$, m.p.: $109-111^{\circ} \mathrm{C} . R_{\mathrm{f}}=0.45$. IR (KBr) $v_{\max } / \mathrm{cm}^{-1}: 3364(\mathrm{NH})$, $1673(\mathrm{C}=\mathrm{O}) .{ }^{1} \mathrm{H}$ NMR (500 MHz, DMSO-d 6 ), $\delta / \mathrm{ppm}$ : $3.38-3.52\left(\mathrm{~m}, 2 \mathrm{H}, \mathrm{COCH}_{2}\right), 4.53(\mathrm{~b}, 1 \mathrm{H}, \mathrm{NH}), 4.95(\mathrm{t}$, $J=6.75 \mathrm{~Hz}, 1 \mathrm{H}, \mathrm{NCH}), 6.50-8.00$ (m, 13H, ArH). MS (EI) $m / z=353\left(\mathrm{M}^{+}, 6.01\right)$. Anal. Calcd. for $\mathrm{C}_{21} \mathrm{H}_{17} \mathrm{ClFNO} ; \mathrm{MW}=353.82: \mathrm{C}, 71.29 ; \mathrm{H}, 4.84 ; \mathrm{N}$, 3.96. Found: C, $71.50 ; \mathrm{H}, 4.41 ; \mathrm{N}, 3.80 \%$.

\section{1-(4-Chlorophenyl)-3-(4-fluorophenyl)-3-(4-fluoro-}

phenylamino)propan-1-one (4j): White solid, yield: 90 $\%$, m.p.: $80-82{ }^{\circ} \mathrm{C} . R_{\mathrm{f}}=0.38$. IR (KBr) $v_{\max } / \mathrm{cm}^{-1}: 3365$ $(\mathrm{NH}), 1673(\mathrm{C}=\mathrm{O}) .{ }^{1} \mathrm{H}$ NMR (500 MHz, DMSO-d 6 ), $\delta / \mathrm{ppm}: 3.35-3.47\left(\mathrm{~m}, 2 \mathrm{H}, \mathrm{COCH}_{2}\right), 4.40(\mathrm{~s}, 1 \mathrm{H}, \mathrm{NH})$, 4.90 (t, $J=6.72 \mathrm{~Hz}, 1 \mathrm{H}, \mathrm{NCH}), 6.40-7.91(\mathrm{~m}, 12 \mathrm{H}$, ArH). MS (EI) $m / z=371\left(\mathrm{M}^{+}, 15.19 \%\right)$. Anal Calcd. for $\mathrm{C}_{21} \mathrm{H}_{16} \mathrm{ClF}_{2} \mathrm{NO} ; \mathrm{MW}=371.81: \mathrm{C}, 67.84 ; \mathrm{H}, 4.34 ; \mathrm{N}$, 3.77. Found C, 67.44; H, 4.10; N, $3.89 \%$.

\section{1-(4-Bromophenyl)-3-(4-fluorophenyl)-3-(phenyl-}

amino)propan-1-one (4k): White solid, yield: $82 \%$, m.p.: $112-114{ }^{\circ} \mathrm{C} . R_{\mathrm{f}}=0.45$. IR $(\mathrm{KBr}) v_{\max } / \mathrm{cm}^{-1}: 3365$ $(\mathrm{NH}), 1673(\mathrm{C}=\mathrm{O}) .{ }^{1} \mathrm{H}$ NMR (500 MHz, $\left.\mathrm{DMSO}^{-} \mathrm{d}_{6}\right)$, $\delta / \mathrm{ppm}: 3.25-3.57\left(\mathrm{~m}, 2 \mathrm{H}, \mathrm{COCH}_{2}\right), 4.44(\mathrm{~s}, 1 \mathrm{H}, \mathrm{NH})$, $4.93(\mathrm{t}, J=6.52 \mathrm{~Hz}, 1 \mathrm{H}, \mathrm{NCH}), 6.43-7.86(\mathrm{~m}, 13 \mathrm{H}$, ArH). ${ }^{13} \mathrm{C}$ NMR (125 MHz, DMSO-d 6 ), $\delta / \mathrm{ppm}: 197.05$ (CO), 163.97, 162.55, 148.15, 140.53, 136.26, 132.29, 130.64, 129.27, 129.04, 127.82, 116.49, 115.62, 115.45, $113.40(\mathrm{ArC}, \mathrm{ArCH}), 52.80(\mathrm{CHNH}), 46.91\left(\mathrm{CH}_{2}\right) \mathrm{MS}$ (EI) $m / z=398\left(\mathrm{M}^{+}, 5.54 \%\right)$. Anal. Calcd. for $\mathrm{C}_{21} \mathrm{H}_{17} \mathrm{BrFNO} ; \mathrm{MW}=398.27: \mathrm{C}, 63.33 ; \mathrm{H}, 4.30 ; \mathrm{N}$, 3.52. Found C, 63.77; H, 4.46; N, $3.99 \%$.

1-(4-Bromophenyl)-3-(4-fluorophenyl)-3-(4-fluorophenylamino)propan-1-one (4l): White solid, yield: 82 \%, m.p.: $94-96{ }^{\circ} \mathrm{C} . R_{\mathrm{f}}=0.50$. IR (KBr) $v_{\max } / \mathrm{cm}^{-1}: 3362$ $(\mathrm{NH}), 1675(\mathrm{C}=\mathrm{O}) .{ }^{1} \mathrm{H}$ NMR (500 $\left.\mathrm{MHz}, \mathrm{DMSO}^{-} \mathrm{d}_{6}\right)$, $\delta /$ ppm: 3.33-3.47 (m, 2H, $\left.\mathrm{COCH}_{2}\right), 4.40(\mathrm{~b}, 1 \mathrm{H}, \mathrm{NH})$, $4.90(\mathrm{t}, J=6.1 \mathrm{~Hz}, 1 \mathrm{H}, \mathrm{NCH}), 6.42-7.78(\mathrm{~m}, 12 \mathrm{H}$, ArH). MS (EI) $m / z=416\left(\mathrm{M}^{+}, 15.20 \%\right)$. Anal. Calcd. for $\mathrm{C}_{21} \mathrm{H}_{16} \mathrm{BrF}_{2} \mathrm{NO} ; \mathrm{MW}=416.26: \mathrm{C}, 60.59 ; \mathrm{H}, 3.87 ; \mathrm{N}$, 3.36. Found $\mathrm{C}, 60.33$; $\mathrm{H}, 3.44 ; \mathrm{N}, 3.13 \%$.
1-(2-Bromophenyl)-3-(4-fluorophenyl)-3-(phenylamino) propan-1-one $(4 \mathrm{~m})$ : Yellow solid, yield $77 \%$, m.p.: $133-135{ }^{\circ} \mathrm{C}, R_{\mathrm{f}}=0.33$. IR $(\mathrm{KBr}) v_{\max } / \mathrm{cm}^{-1}: 3397(\mathrm{NH})$, $1687(\mathrm{C}=\mathrm{O}) .{ }^{1} \mathrm{H}$ NMR $(500 \mathrm{MH} z$, DMSO-d 6 ), $\delta / \mathrm{ppm}$ : $3.35-3.46\left(\mathrm{~m}, 2 \mathrm{H}, \mathrm{COCH}_{2}\right), 4.37(\mathrm{~s}, 1 \mathrm{H}, \mathrm{NH}), 5.00(\mathrm{t}, J$ $=6.50 \mathrm{~Hz}, 1 \mathrm{H}, \mathrm{NCH}), 6.44-7.90(\mathrm{~m}, 13 \mathrm{H}, \mathrm{ArH}) . \mathrm{MS}$ (EI) $m / z=398\left(\mathrm{M}^{+}, 17.10 \%\right)$. Anal. Calcd. for $\mathrm{C}_{21} \mathrm{H}_{17} \mathrm{BrFNO}$; $\mathrm{MW}=398.27: \mathrm{C}, 63.33 ; \mathrm{H}, 4.30 ; \mathrm{N}$, 3.52. Found C, 63.44; H, 4.80; N, $3.88 \%$.

1-(2-Bromophenyl)-3-(4-fluorophenyl)-3-(4-fluoro-

phenylamino)propan-1-one (4n): Creamy solid, yield: $77 \%$, m.p. $220-223{ }^{\circ} \mathrm{C} . R_{\mathrm{f}}=0.28$. IR $(\mathrm{KBr}) v_{\max } / \mathrm{cm}^{-1}$ : $3359(\mathrm{NH}), 1686(\mathrm{C}=\mathrm{O}) .{ }^{1} \mathrm{H}$ NMR (500 MHz, DMSO$\left.\mathrm{d}_{6}\right), \delta / \mathrm{ppm}: 3.33-3.41\left(\mathrm{~m}, 2 \mathrm{H}, \mathrm{COCH}_{2}\right), 4.37(\mathrm{~s}, 1 \mathrm{H}$, $\mathrm{NH}), 4.98$ (t, $J=6.52 \mathrm{~Hz}, 1 \mathrm{H}, \mathrm{NCH}), 6.42-7.99(\mathrm{~m}$, 12H, ArH). MS (EI) $m / z=419\left(\mathrm{M}^{+} 3 \mathrm{H}\right)(38.9 \%)$. Anal. Calcd. for $\mathrm{C}_{21} \mathrm{H}_{16} \mathrm{BrF}_{2} \mathrm{NO}$; $\mathrm{MW}=416.26: \mathrm{C}, 60.59 ; \mathrm{H}$, 3.87; N, 3.36. Found C, 60.88; H, 3.71; N, $3.23 \%$.

The synthesis of the compounds (5a-e), yellow solids: $\mathrm{Ar}_{1}=$ a) $\mathrm{C}_{6} \mathrm{H}_{5}$, b) $\mathrm{C}_{6} \mathrm{H}_{4}-\mathrm{CH}_{3}-p$, c) $\mathrm{C}_{6} \mathrm{H}_{4}-\mathrm{Cl}-p$, d) $\mathrm{C}_{6} \mathrm{H}_{4}-$ $\mathrm{Br}-p$, e) $\mathrm{C}_{6} \mathrm{H}_{4}$ - $\mathrm{Br}-o$ has been described previously. ${ }^{28-31}$

\section{General Method for Preparation of 5-(4-fluoro- benzylidene)-2-thioxothiazolidin-4-one (6)}

A mixture of 4-fluorobenzaldehyde $(2.0 \mathrm{mmol})$, Rhodanine (2.0 mmol), and SSA $(0.11 \mathrm{~g}, 0.04 \mathrm{~mol} \%)$ was stirred in $\mathrm{EtOH}(5 \mathrm{ml})$ at room temperature for $6 \mathrm{~h}$. The reaction was monitored on TLC (.petroleum ether / ethyl acetate (4:1), $R_{\mathrm{f}}=0.33$. When the reaction completed, $\mathrm{CH}_{2} \mathrm{Cl}_{2}(5 \mathrm{ml})$ was added and catalyst was removed by filtration. The Filtrate washed with saturated $\mathrm{NaHCO}_{3}$ (aqueous), brine and dried over anhydrous $\mathrm{Na}_{2} \mathrm{SO}_{4}$, filtered and the obtained clear filtrate evaporated under reduced pressure to dryness. The obtained residue was purified by silica-gel chromatographic methods to obtain product (6) (yield $80 \%$ ).

5-(4-Fluorobenzylidene)-2-thioxothiazolidin-4-one (6): Orange solid, yield $80 \%$, m.p.: $219-220^{\circ} \mathrm{C} .{ }^{32} \mathrm{IR}(\mathrm{KBr})$ $v_{\max } / \mathrm{cm}^{-1}: 3424(\mathrm{NH}), 1698(\mathrm{C}=\mathrm{O}), 1189(\mathrm{~S}=\mathrm{O}) .{ }^{1} \mathrm{H}$ NMR (500 MHz, DMSO-d 6 ), $\delta /$ ppm: 7.36-7.64 (m, 5H, $\mathrm{ArH}^{+}=\mathrm{CH}$ ), $13.83($ b, $1 \mathrm{H}, \mathrm{NH})$. MS (EI) $m / z=239$ $\left(\mathrm{M}^{+}\right.$, 3.55). Anal Calcd. for $\mathrm{C}_{10} \mathrm{H}_{6} \mathrm{FNOS}_{2}$; $\mathrm{MW}=$ 239.29: C, 50.19; H, 2.53; F, 7.94; N, 5.85. Found C, $50.66 ; \mathrm{H}, 2.40 ; \mathrm{F}, 7.80 ; \mathrm{N}, 5.65 \%$.

\section{General Method for Preparation of 2-(4-fluoro- phenyl) benzothiazole (8)}

A mixture of 4-fluorobenzaldehyde (2.0 mmol), 2aminothiophenol $(2.0 \mathrm{mmol})$, and SSA $(0.11 \mathrm{~g}, 0.04$ mol \%) was stirred in $\mathrm{EtOH}(5 \mathrm{ml})$ at room temperature for $7 \mathrm{~h}$. The reaction was monitored on TLC (petroleum ether / ethyl acetate (4:1), $R_{\mathrm{f}}=0.75$. When the reaction completed; $\mathrm{CH}_{2} \mathrm{Cl}_{2}(5 \mathrm{ml})$ was added and the catalyst was removed by filtration. The obtained filtrate washed 
Table 1. Optimization of reaction conditions for the formation of representative compound (4a)

\begin{tabular}{|c|c|c|c|c|c|c|}
\hline Entry $^{(a)}$ & Catalyst & solvent & Catalyst / $\mathrm{mol} \%$ & Time $/ h^{(b)}$ & Yield / \% ${ }^{(\mathrm{c})}$ & Ratio $(\mathbf{4 a} / \mathbf{5 a})$ \\
\hline 1 & SSA & $\mathrm{MeOH}$ & 0.04 & 14 & 55 & $57 / 43$ \\
\hline 2 & SSA & $\mathrm{CH}_{3} \mathrm{CN}$ & 0.04 & 15 & 63 & $62 / 38$ \\
\hline 3 & SSA & $\mathrm{CH}_{2} \mathrm{Cl}_{2}$ & 0.04 & 16 & 60 & $55 / 45$ \\
\hline 4 & SSA & EtOH & 0.04 & 13 & 80 & $70 / 30$ \\
\hline 5 & SSA & $\mathrm{EtOH}$ & 0.1 & 13 & 50 & $20 / 80$ \\
\hline 6 & SSA & EtOH & 0.02 & 14 & 65 & $60 / 40$ \\
\hline 7 & $\mathrm{FeCl}_{3}$ & EtOH & 0.04 & 14 & 75 & $57 / 43$ \\
\hline 8 & $\mathrm{SiCl}_{4}$ & $\mathrm{CH}_{2} \mathrm{Cl}_{2}$ & 0.04 & 10 & 60 & $10 / 90$ \\
\hline 9 & $\mathrm{HClO}_{4} \mathrm{SiO}_{2}$ & $\mathrm{EtOH}$ & 0.04 & 10 & 70 & $30 / 70$ \\
\hline 10 & $\mathrm{Me}_{3} \mathrm{ClSi}$ & $\mathrm{EtOH}$ & 0.04 & 9 & 65 & $20 / 80$ \\
\hline
\end{tabular}

(a) Reaction carried out in the appropriate solvent using 4-fluorobenzaldehyde ( $2 \mathrm{mmol})$, acetophenone $(2 \mathrm{mmol})$ and aniline $(2 \mathrm{mmol})$ at room temperature.

(b) Detected by TLC.

(c) Isolated yields after silica-gel chromatography.

with saturated $\mathrm{NaHCO}_{3}$ (aqueous), brine and dried over anhydrous $\mathrm{Na}_{2} \mathrm{SO}_{4}$, evaporated under reduced pressure to dryness. The obtained residue purified by silica-gel chromatography to give (8) (yield $85 \%$ ).

2-(4-Fluorophenyl)benzothiazole (8): White solid, yield: $85 \%$, m.p.: $98-100{ }^{\circ} \mathrm{C} .{ }^{33}{ }^{1} \mathrm{H}$ NMR (500 MHz, DMSO$\mathrm{d}_{6}$ ), $\delta$ ppm: 7.17-8.13(m, 8H, ArH). MS (EI) $m / z=229$ $\left(\mathrm{M}^{+}, 17.02 \%\right)$. Anal Calcd. for $\mathrm{C}_{13} \mathrm{H}_{8} \mathrm{FNS}$; $\mathrm{MW}=$ 229.27: C, 68.10; H, 3.52; N, 6.11. Found: C, 68.22; H, $3.42 ; \mathrm{N}, 6.30 \%$.

\section{Anti-microbial Screening}

The anti-bacterial activity of the synthesized compounds was tested against two Gram- negative bacteria: Escherichia coli NCTC 10416, Pseudomonas aeruginosa NCIB 9016, and two Gram-positive bacteria: Bacillus subtilis NCIB 3610, Staphylococcus aureus NCTC 7447, and one fungus namely: Candida albicans IMRU 3669 using nutrient agar medium.

\section{Paper-disc Diffusion Technique}

A sterilized (autoclaved at $120{ }^{\circ} \mathrm{C}$ for $30 \mathrm{~min}$ ) medium $\left(40-50{ }^{\circ} \mathrm{C}\right)$ was incubated $(1 \mathrm{ml} / 100 \mathrm{ml}$ of medium $)$

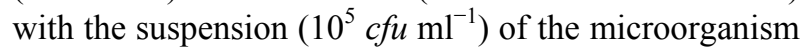
(matched to McFarland barium sulphate standard) and poured into a petri-dish to give a depth of 3-4 $\mathrm{mm}$. The paper impregnated with the test compounds $\left(\mu \mathrm{g} / \mathrm{ml}^{-1}\right.$ in methanol) was placed on the solidified medium. The plates were pre-incubated for $1 \mathrm{~h}$ at room temperature, incubated at $37{ }^{\circ} \mathrm{C}$ for 24 and $48 \mathrm{hr}$ for anti-bacterial and anti-fungal activities respectively. Ampicillin (mg/disc) was used as a standard for antibacterial and anti-fungal activity respectively. The observed inhibition zones are depicted in (Table 3).

Conformational Search and Flexible Alignment Conformational analysis and flexible alignment of the tested compounds were carried out using the software $\left(\mathrm{MOE}^{34}\right.$ of Chemical Computing Group Inc., on a Core
2 duo $3.00 \mathrm{GH} z$ workstation). The molecules were built by the builder module of MOE. The geometry optimized using the MMFF94 force-field followed by a flexible alignment with systematic conformational search. Lowest energy aligned conformation(s) identified through the analysis module of DSV.

\section{RESULTS AND DISCUSSION}

In continuation of our studies on silica reagents, ${ }^{35-37}$ the present work was directed towards using silica sulfuric acid (SSA) catalyst for the synthesis of new $\beta$-amino carbonyls derivatives. Initial studies were performed between 4-fluorobenzaldehyde (1), acetophenones (2), and anilines (3) in the presence of this catalyst at room temperature (Scheme 1) and TLC plates monitored the reaction progress.

For optimization, the reaction was carried out under various conditions using different catalysts and solvents to probe the role played by SSA to find out the best catalyst and solvent as shown in Table (1). From the obtained results, the best catalyst and solvent in terms of yield and time was silica sulfuric acid (0.04 mol) and EtOH (Table 1, entry 4). Therefore, EtOH (solvent) and SSA (catalyst) were used throughout the present study.

Substrate scope investigations revealed that a variety of aromatic ketones $\mathbf{2}$ and amines $\mathbf{3}$ reacted smoothly with 4-fluorobenzaldehyde $\mathbf{1}$ to afford the corresponding $\beta$-amino fluorinated ketones $(\mathbf{4 a}-\mathbf{n})$ and the aldol products (5a-e) (Scheme 1 and Table 2).

From the obtained results, it was noticed that, both yield and reaction time depended on the nature of substituent. Thus, the presence of the electron-withdrawing group on the aromatic ketones (entry 10) increased the yield of $\beta$-amino ketones with reducing the reaction time (Table 2). Noteworthy to observe that when using aliphatic amines such as methylamine and $n$-butyl amine instead of aromatic amines under the same reac- 
<smiles>O=Cc1ccc(F)cc1</smiles>

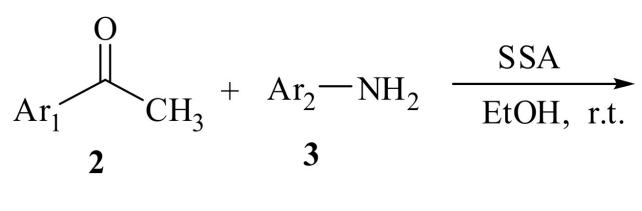<smiles>NC(CC([AlH2])[AlH2])c1ccc(F)cc1</smiles><smiles>O=C([Al])/C=C/c1ccc(F)cc1</smiles>

Scheme 1. One-pot synthesis of $\beta$-amino fluorinated carbonyl compounds (4a-n).

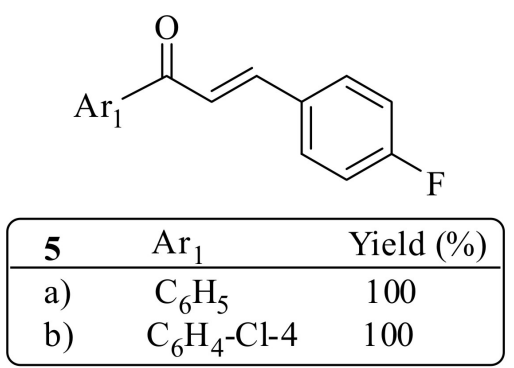

Scheme 2. Reaction of methylamine or $n$-butyl amine with 4-fluorobenzaldehyde 1, aromatic ketones 2 in EtOH in presence of SSA at room temperature.

tion conditions, the corresponding aldol condensation products (5a and c) were isolated as clean cut compounds (100\% yield) without isolating the expected $\beta$-amino fluorinated ketones of type 4 (Scheme 2).

A possible mechanism of the Mannich-type reaction that involves the use of SSA as catalyst in ethanol is proposed (Scheme 3). When SSA was added to the reaction mixture, the carbonyl oxygen atom of the aldehyde becomes activated and this lead to formation of the intermediate I. Then, aniline (as a nucleophile) attacks the activated carbonyl group of benzaldehyde forming a hydrogen bond (between $\mathrm{H}$ and $\mathrm{O}$ ) with $\mathrm{SiO}_{2}-\mathrm{SO}_{3} \mathrm{H}$, affording the intermediate II with splitting of a water molecule through intramolecular rearrangement to the intermediate III. In the mean time the carbonyl oxygen atom of acetophone is activated by SSA, forming (enol form) intermediate IV. In the reaction medium, the $\pi$-electrons of the activated (or non-stabilized) imine delocalized towards the activated enol to form a new carbon-carbon bond through the reface of the double bond plane. The $\pi$-electrons of the activated enol redistribute to give keto form (accompanied by the transfer of hydrogen atom to nitrogen atom). Finally, the Mannich adduct is formed and catalyst (SSA) renewed again (Scheme 3).

The present work was continued to explore replacing of acetophenone derivatives with other reagents. Thus, when the reaction was carried out using rhodanine under the same reaction conditions 5-(4-fluorobenzylidene)-2-thioxothiazolidin-4-one $(6)^{38}$ (yield $80 \%$ ) was obtained as a sole product rather than the expected product 5-((4-fluoro-phenyl)(phenyl amino)methyl)-2thioxothiazolidin-4-one (7). Structure of product (6) was elucidated chemically by reacting rhodanine with 4fluorobenzaldehyde under the same reaction conditions, which gave the same product (m.p and mixed m.p.). Also, upon using 2-aminothiophenol instead of aniline derivatives 2-(4-fluorophenyl)benzo-thiazole $(\mathbf{8})^{39}$ (obtained as

Table 2. One-pot synthesis of $\beta$-amino fluorinated carbonyl compounds (4a-n)

\begin{tabular}{|c|c|c|c|c|c|c|c|c|}
\hline Entry & 2 & 3 & & $4 a-n$ & & & $a-e^{(a)}$ & $\begin{array}{l}\text { Reaction }{ }^{(b)} \\
\text { Time / h }\end{array}$ \\
\hline & $\mathrm{Ar}_{1}$ & $\mathrm{Ar}_{2}$ & $\mathrm{Ar}_{1}$ & $\mathrm{Ar}_{2}$ & Yield / \% & $\mathrm{Ar}_{1}$ & Yield / \% & \\
\hline 1 & $\mathrm{C}_{6} \mathrm{H}_{5}$ & $\mathrm{C}_{6} \mathrm{H}_{5}$ & a) $\mathrm{C}_{6} \mathrm{H}_{5}$ & $\mathrm{C}_{6} \mathrm{H}_{5}$ & 70 & $5 \mathbf{a}$ & 30 & 13 \\
\hline 2 & $\mathrm{C}_{6} \mathrm{H}_{5}$ & $\mathrm{C}_{6} \mathrm{H}_{4}-\mathrm{CH}_{3}-p$ & b) $\mathrm{C}_{6} \mathrm{H}_{5}$ & $\mathrm{C}_{6} \mathrm{H}_{4}-\mathrm{CH}_{3}-p$ & 68 & $5 \mathbf{a}$ & 32 & 11 \\
\hline 3 & $\mathrm{C}_{6} \mathrm{H}_{5}$ & $\mathrm{C}_{6} \mathrm{H}_{4}-\mathrm{F}-p$ & c) $\mathrm{C}_{6} \mathrm{H}_{5}$ & $\mathrm{C}_{6} \mathrm{H}_{4}-\mathrm{F}-p$ & 72 & $5 \mathbf{a}$ & 28 & 11 \\
\hline 4 & $\mathrm{C}_{6} \mathrm{H}_{5}$ & $\mathrm{C}_{6} \mathrm{H}_{4}-\mathrm{Cl}-p$ & d) $\mathrm{C}_{6} \mathrm{H}_{5}$ & $\mathrm{C}_{6} \mathrm{H}_{4}-\mathrm{Cl}-p$ & 72 & $5 \mathbf{a}$ & 28 & 12 \\
\hline 5 & $\mathrm{C}_{6} \mathrm{H}_{5}$ & $\mathrm{C}_{6} \mathrm{H}_{4}-\mathrm{Br}-p$ & e) $\mathrm{C}_{6} \mathrm{H}_{5}$ & $\mathrm{C}_{6} \mathrm{H}_{4}-\mathrm{Br}-p$ & 70 & $5 \mathbf{a}$ & 30 & 12 \\
\hline 6 & $\mathrm{C}_{6} \mathrm{H}_{4}-\mathrm{CH}_{3}-p$ & $\mathrm{C}_{6} \mathrm{H}_{5}$ & f) $\mathrm{C}_{6} \mathrm{H}_{5}$ & $\mathrm{C}_{6} \mathrm{H}_{4}-\mathrm{CH}_{3-p}$ & 76 & $5 \mathbf{b}$ & 33 & 15 \\
\hline 7 & $\mathrm{C}_{6} \mathrm{H}_{4}-\mathrm{CH}_{3}-p$ & $\mathrm{C}_{6} \mathrm{H}_{4}-\mathrm{CH}_{3}-p$ & g) $\mathrm{C}_{6} \mathrm{H}_{4}-\mathrm{CH}_{3}-p$ & $\mathrm{C}_{6} \mathrm{H}_{4}-\mathrm{CH}_{3}-p$ & 66 & $5 \mathbf{b}$ & 34 & 13 \\
\hline 8 & $\mathrm{C}_{6} \mathrm{H}_{4}-\mathrm{CH}_{3}-p$ & $\mathrm{C}_{6} \mathrm{H}_{4}-\mathrm{F}-p$ & h) $\mathrm{C}_{6} \mathrm{H}_{4}-\mathrm{CH}_{3}-p$ & $\mathrm{C}_{6} \mathrm{H}_{4}-\mathrm{F}-p$ & 66 & $5 b$ & 34 & 13 \\
\hline 9 & $\mathrm{C}_{6} \mathrm{H}_{4}-\mathrm{Cl}-p$ & $\mathrm{C}_{6} \mathrm{H}_{5}$ & i) $\mathrm{C}_{6} \mathrm{H}_{4}-\mathrm{Cl}-p$ & $\mathrm{C}_{6} \mathrm{H}_{5}$ & 87 & $5 c$ & 13 & 7 \\
\hline 10 & $\mathrm{C}_{6} \mathrm{H}_{4}-\mathrm{Cl}-p$ & $\mathrm{C}_{6} \mathrm{H}_{4}-\mathrm{F}-p$ & j) $\mathrm{C}_{6} \mathrm{H}_{4}-\mathrm{Cl}-p$ & $\mathrm{C}_{6} \mathrm{H}_{4}-\mathrm{F}-p$ & 90 & $5 c$ & 10 & 6 \\
\hline 11 & $\mathrm{C}_{6} \mathrm{H}_{4}-\mathrm{Br}-p$ & $\mathrm{C}_{6} \mathrm{H}_{5}$ & k) $\mathrm{C}_{6} \mathrm{H}_{4}-\mathrm{Br}-p$ & $\mathrm{C}_{6} \mathrm{H}_{5}$ & 82 & $5 d$ & 18 & 8 \\
\hline 12 & $\mathrm{C}_{6} \mathrm{H}_{4}-\mathrm{Br}-p$ & $\mathrm{C}_{6} \mathrm{H}_{4}-\mathrm{F}-p$ & 1) $\mathrm{C}_{6} \mathrm{H}_{4}-\mathrm{Br}-p$ & $\mathrm{C}_{6} \mathrm{H}_{4}-\mathrm{F}-p$ & 82 & $5 d$ & 18 & 8 \\
\hline 13 & $\mathrm{C}_{6} \mathrm{H}_{4}-\mathrm{Br}-\mathrm{O}$ & $\mathrm{C}_{6} \mathrm{H}_{5}$ & m) $\mathrm{C}_{6} \mathrm{H}_{4}-\mathrm{Br}-\mathrm{O}$ & $\mathrm{C}_{6} \mathrm{H}_{5}$ & 77 & $5 e$ & 23 & 10 \\
\hline 14 & $\mathrm{C}_{6} \mathrm{H}_{4}-\mathrm{Br}-\mathrm{O}$ & $\mathrm{C}_{6} \mathrm{H}_{4}-\mathrm{F}-p$ & n) $\mathrm{C}_{6} \mathrm{H}_{4}-\mathrm{Br}-O$ ) & $\mathrm{C}_{6} \mathrm{H}_{4}-\mathrm{F}-p$ & 77 & $5 e$ & 23 & 9 \\
\hline
\end{tabular}

(a) 5a-e: $\mathrm{Ar}_{1}=$ a) $\mathrm{C}_{6} \mathrm{H}_{5}$, b) $\mathrm{C}_{6} \mathrm{H}_{4}-\mathrm{CH}_{3}-p$, c) $\mathrm{C}_{6} \mathrm{H}_{4}-\mathrm{Cl}-p$, d) $\mathrm{C}_{6} \mathrm{H}_{4}-\mathrm{Br}-p$, e) $\mathrm{C}_{6} \mathrm{H}_{4}-\mathrm{Br}-o$.

(b) Stirring time at room temperature. 


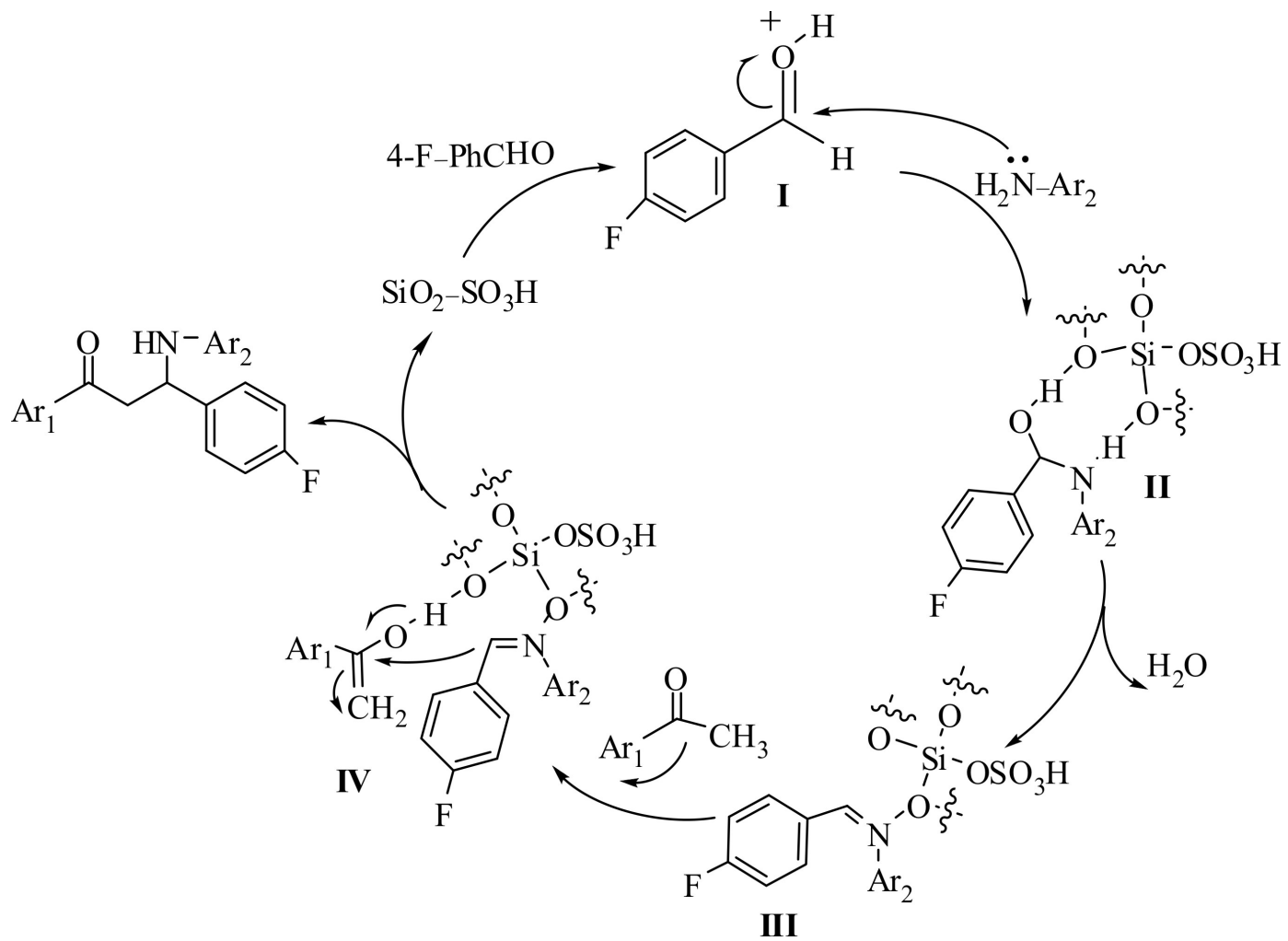

Scheme 3. Proposed mechanism of the direct Mannich reaction catalysed by silica sulfuric acid.

authentic sample from reaction of 2-aminothiophenol with 4-fluorobenzaldehyde) was afforded (85\% yield) without isolation of the expected 3-(4-fluorophenyl)-3-(2mercaptophenylamino)-1-(4-sub-stitutedphenyl)-propan1-one (9) (Schemes 4 and 5).

Unequivocal proofs for the role played by steric hindrance could come from the reaction of rhodanine and 2-aminothiophenol, which gave products (6) and (8) respectively as sole products. Structure of products (6) and (8) was confirmed by spectroscopic methods and elemental analyses.

\section{Biological Activity}

Antibacterial Activity

The synthesized $\beta$-amino ketones (4a-n), 5-(4fluorobenzylidene)-2-thioxothia zolidin-4-one (6) and 2(4-Fluorophenyl) benzothiazole (8) were tested for their in vitro antibacterial activity by using paper disc diffusion technique. ${ }^{40-44}$ The tested microorganism strains were (Gram-negative bacteria: Escherichia coli NCTC 10416, Pseudomonas aeruginosa NCIB 9016 and Gram-positive bacteria: Bacillus subtilis NCIB 3610,<smiles>CC(C)=CCc1ccc(F)cc1</smiles>

Scheme 4. Synthesis of 5-(4-fluorobenzylidene)-2-thioxothiazolidin-4-one (6). 


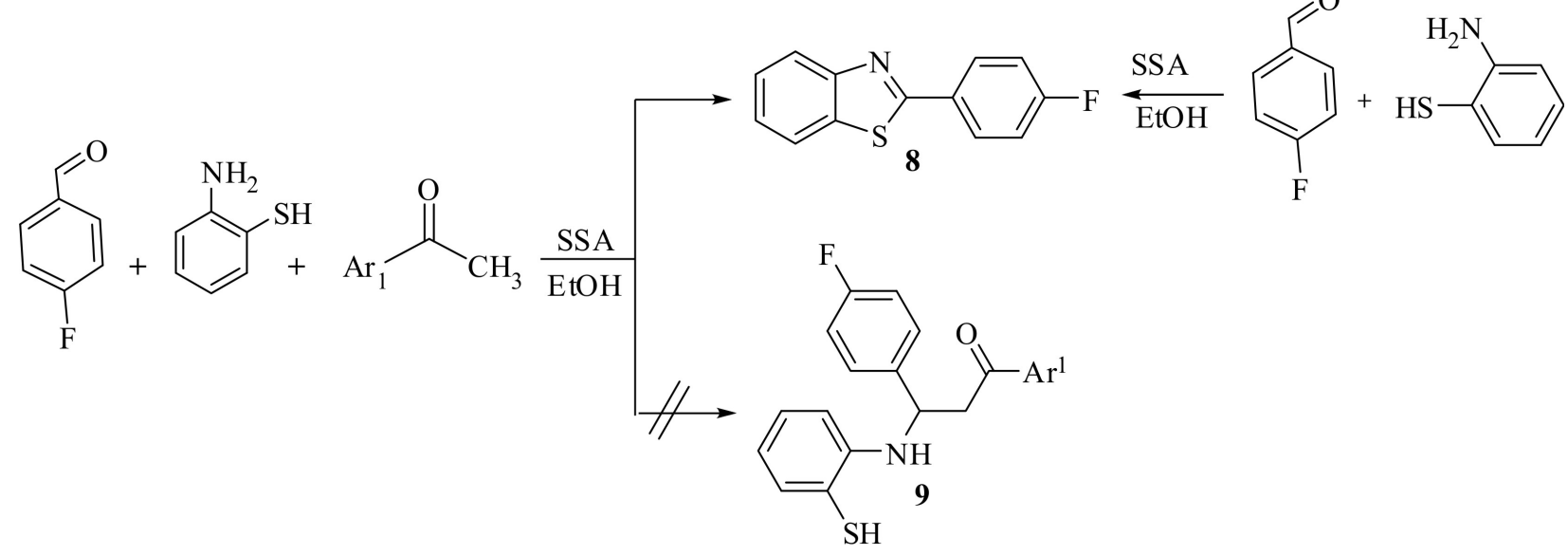

$$
\left.\mathrm{Ar}^{1} \mathrm{a}\right)=\mathrm{C}_{6} \mathrm{H}_{5} ; \text { b) } o-\mathrm{BrC}_{6} \mathrm{H}_{5} ; \text { c) } p-\mathrm{ClC}_{6} \mathrm{H}_{5} ; \text { d) } p-\mathrm{CH}_{3}-\mathrm{C}_{6} \mathrm{H}_{5}
$$

Scheme 5. Synthesis of 2-(4-fluorophenyl)benzothiazole (8).

Staphylococcus aureus NCTC 7447), Ampicillin was used as standard drug control. The results of antimicrobial activity values are furnished in (Table 3 ); and depicted graphically in (Figure 1). The data presented in (Table 3) cleared that, compound (4n) was the most active compound against all the tested bacterial strains; but compound (4m) was more potent against $E$. coli and $S$. aureus than the standard drug Ampicillin. Other synthesized compounds showed weak activity and / or loss activity against the tested bacterial strains.

\section{Antifungal Activity}

The in vitro antifungal studies of all the synthesized compounds (4a-n, 6 and 8) were tested against Candida albicans IMRU 3669, Ampicillin was used as reference drug and their inhibition zone diameter values were depicted in (Table 3 ) and graphically in (Figure 1). In general, all the synthesized compounds exerted weak to inactive in vitro antifungal activity against all the tested organisms. Moreover, compounds (4m and $\mathbf{4 n}$ ) were more effective against the tested fungus than the standard drug Ampicillin.

Table 3. Anti-microbial activity of the synthesized compounds

\begin{tabular}{lccccc}
\hline \multicolumn{7}{c}{ In vitro activity-zone of inhibition $/ \mathrm{mm}^{(\mathrm{a})}$} \\
\hline Comp No. & E. coli & B. subtilis & S. aureus & P. aeruginosa & C. albicans \\
$\mathbf{4 a}$ & - & - & - & - & - \\
$\mathbf{4 b}$ & - & - & - & - & - \\
$\mathbf{4 c}$ & - & - & - & - & - \\
$\mathbf{4 d}$ & 9 & 8 & 10 & 11 & 9 \\
$\mathbf{4} \mathbf{e}$ & - & - & - & - & - \\
$\mathbf{4 g}$ & - & - & - & - & - \\
$\mathbf{4 h}$ & - & - & - & - & - \\
$\mathbf{4 i}$ & - & - & - & - & - \\
$\mathbf{4} \mathbf{j}$ & - & - & - & - & - \\
$\mathbf{4 k}$ & 9 & 8 & 8 & 8 & 10 \\
$\mathbf{4}$ & - & - & - & - & - \\
$\mathbf{4}$ & 30 & 15 & 28 & 15 & 30 \\
$\mathbf{4 n}$ & 27 & 35 & 30 & 38 & - \\
$\mathbf{6}$ & - & - & - & - & - \\
$\mathbf{8}$ & - & - & - & - & 17 \\
Ampicillin & 19 & 19 & 18 & 21 & - \\
Chloroform & - & - & - & - & \\
\hline
\end{tabular}

(a) $(-)$ Inactive $(<8 \mathrm{~mm})$, weak activity $(8-12 \mathrm{~mm})$, moderate activity $(12-15 \mathrm{~mm})$, strong activity $(>15)$. 


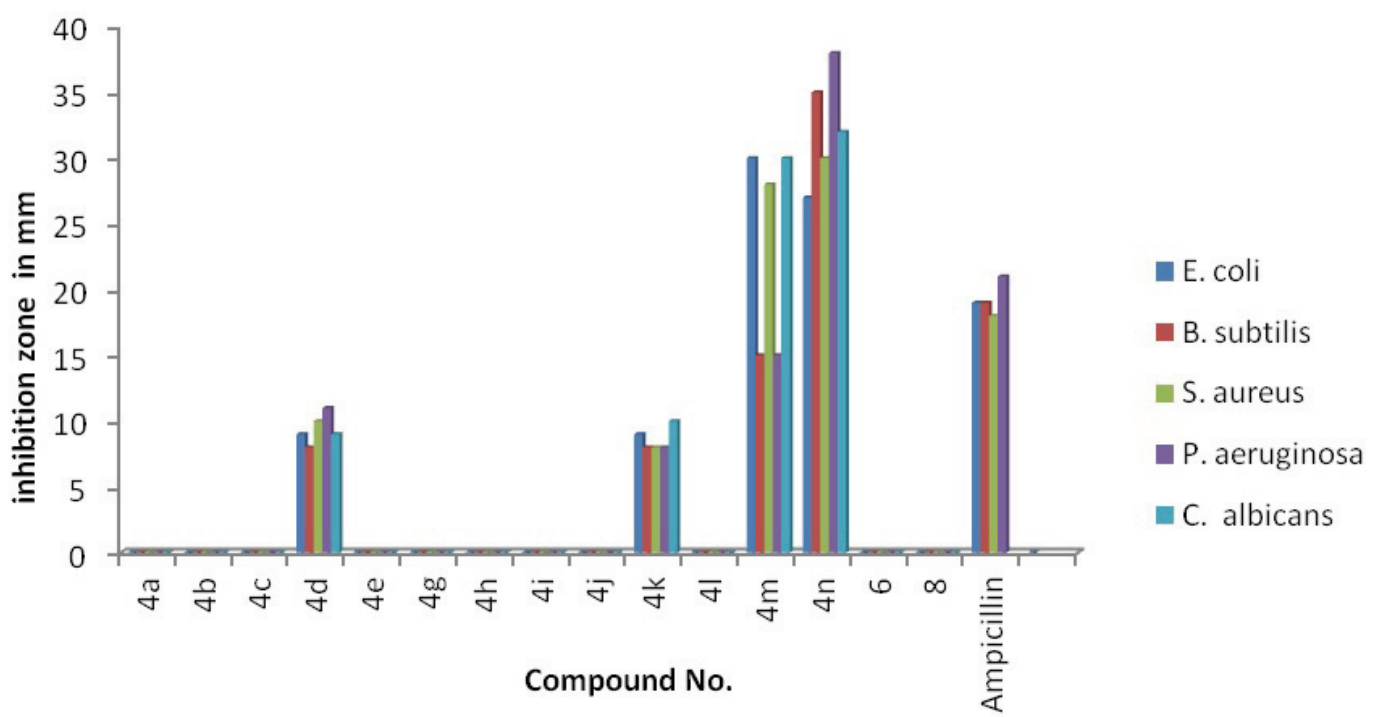

Figure 1. Antimicrobial activities of compounds $(\mathbf{4 a}-\mathbf{n}),(\mathbf{6})$ and $(\mathbf{8})$ against bacterial strains (Gram negative and positive bacteria), and fungal strain.

\section{Structural Activity Relationship}

To obtained clear picture about the structure activity relationship (SAR) for the synthesized compounds, the target compounds were numbered (Figure 2). The activity of the tested compounds must be correlated with structure modifications and variation. The obtained screening results showed that, compounds (4m and $\mathbf{4 n}$ ) are the most active members.

A close survey in vitro antibacterial and antifungal activity profile of the new $\beta$-amino ketones against the tested bacterial and fungal organisms, gave a clear idea about the structure-activity correlations among the studied compounds. The presence of a fluoropheny moiety (phenyl ring $\mathbf{C}$ ) at N-11 with the presence of bromo substitution attached to phenyl ring (A) at the C-6 position compound (4n) exerted a significant varied range of biological activities. In addition, the presence of bromine moiety at C- 6 position (ring A) without substitution (ring $\mathbf{C}$ ) showed significant activity of compound (4n) against E.coli and $C$. albicans, which revealed moderate potency against other microorganisms. For comparison, compounds (4d and 4k), showed weak activity against all microorganisms and the other tested compounds do not

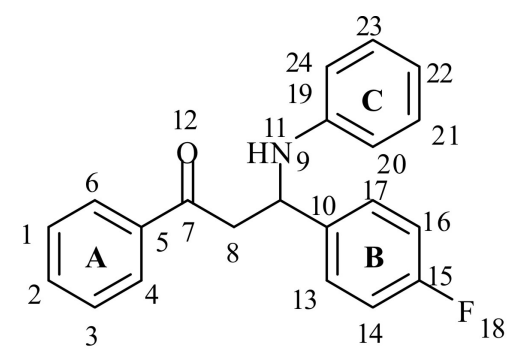

Figure 2. A numbered target molecules (4a-4n). show any activity against any microorganisms. Furthermore, the observed marked antibacterial and antifungal activities could be considered as key steps for the building of novel therapeutic compound with comparable pharmacological features with that of the standard drugs after considering results from toxicology studies.

\section{Docking Studies}

Absorption, Distribution, Metabolism, Elimination (ADME)

Toxic Factors Profiling

Oral bioavailability considerably plays an important role for the development of bioactive molecules as therapeutic agents. Several potential therapeutic agents fail to reach the clinic, because of ADME toxic Factors. Therefore, a computational study for prediction of ADME properties of the molecules was performed for antimicrobial compounds (4d, $\mathbf{k}, \mathbf{m}$ and $\mathbf{4 n}$ ), by the deter-

Table 4. Molecular parameters of the active compounds

\begin{tabular}{lcccc}
\hline Compound & $\boldsymbol{4} \boldsymbol{d}$ & $\mathbf{4} \boldsymbol{4}$ & $\mathbf{4 m}$ & $\boldsymbol{4} \boldsymbol{n}$ \\
\hline TPSA & 29.1 & 29.1 & 29.1 & 29.1 \\
$\log P$ & 5.199 & 5.638 & 5.844 & 5.842 \\
$n \mathrm{ON}$ & 2 & 2 & 2 & 2 \\
$n \mathrm{OHNH}$ & 1 & 1 & 1 & 1 \\
$\operatorname{Lip}-V$ & 1 & 1 & 1 & 1 \\
$\log S$ & -5.52037 & -5.95968 & -6.31578 & -6.31578 \\
$\mathrm{MR}$ & 9.46642 & 9.97162 & 10.24062 & 10.24062 \\
\hline * TPSA: Total & Polar & surface area, Log $P$ : Calculated \\
lipophilicity; $n$ ON: Number of hydrogen bond acceptor; \\
$n$ OHNH: Number of hydrogen bond donor; Lip- $V:$ Number of \\
violation from Lipinski’s rule of five; Log $S:$ Solubility pa- \\
rameter; MR: Molar refractometry.
\end{tabular}




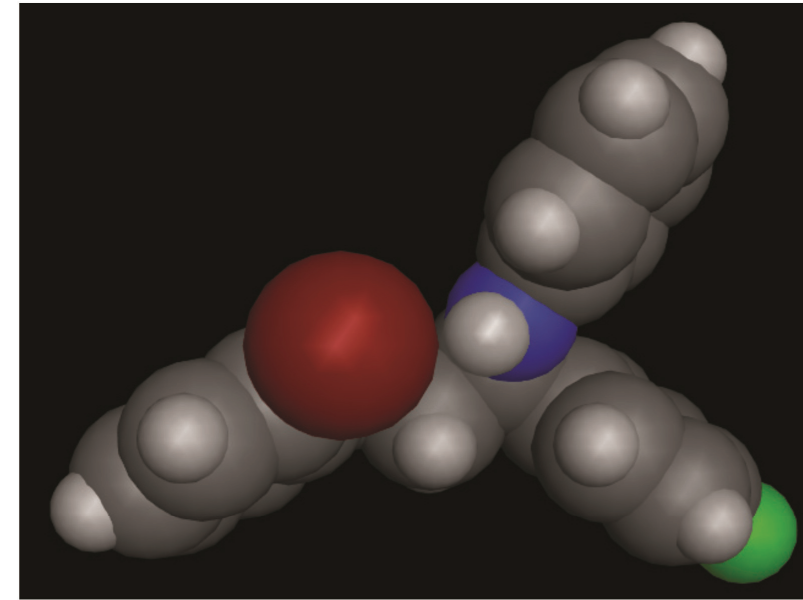

$4 \mathrm{~m}$

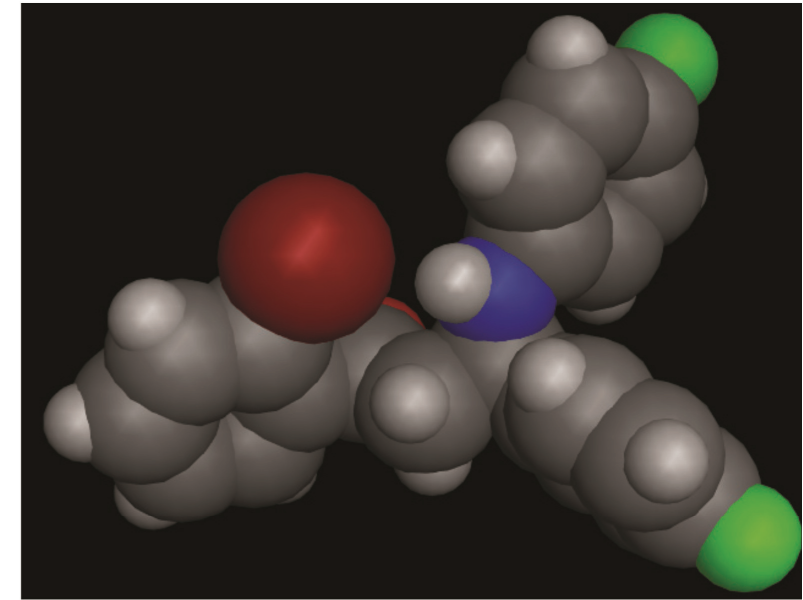

$4 n$

Figure 3. Lowest energy conformers of the most active compounds (4m) and (4n) as representative examples in CPK rendering.

mination of topological polar surface area (TPSA), $C$ $\log P$ and "rule of five" which have been formulated by Lipinski. ${ }^{45}$ The same author established that, a chemical compound could be an orally active drug in humans, if no more than one violation of the following rule: i) $C \log P<5$, ii) number of hydrogen bond donors sites $\leq 5$, iii) number of hydrogen bond acceptors sites $\leq$ 10 , iv) and molecular weight $<500$. In addition, the total polar surface area (TPSA) is another key property linked to drug bioavailability, the passively absorbed molecules with (TPSA>140) have low oral bioavailability. ${ }^{46}$ Calculations were performed using MOE program, ${ }^{47}$ the results were disclosed in (Table 4$)$. The present results revealed that, the $C \log P$ is the partition coefficient between water and octanol (factor of lipophilicity). ${ }^{48}$ Lipophilicity of most compounds is more than 5.0; the molecular weight $(\mathrm{MW}<500)$, hydrogen bond acceptors between ( 1 and 2 ) and hydrogen bond donors (1) which fulfill Lipinski's rule. These data may suggest that, these compounds of good passive oral absorption.

\section{Conformational Analysis}

In order to gain a better insight into the molecular structures of the active compounds (4m and $4 n$ ) and low active compounds (4d and $\mathbf{4 k}$ ). The conformational analysis of the target compounds were performed using MMFF94 force-field ${ }^{49,50}$ (calculations in vacuum, bond dipole option for electrostatics, Polake Ribiere algorithm, RMS gradient of $0.01 \mathrm{kcal} / \mathrm{A} \mathrm{mol}$ ) implemented in MOE 2009.10.). The most stable conformer was fully optimized by $\mathrm{AM}^{49}$ semi-empirical molecular orbital calculation (Figure 3).

The calculation results showed that, the lowest minimization energy structures of the compounds under investigation exhibited a common arrangement and critical distance of the aryl moiety in (ring $\mathbf{C}$ ) from the fluoropheny core (ring B). The optimal distance for the best biological activity was found in $3.12 \AA$ and $3.13 \AA$ for (4m and $4 n)$ respectively, and the higher distance values in rang (3.16-3.18) lead to decrease in activity, as indicated in Figure 4.

\section{Flexible Alignment}

To understand similarity between the threedimensional structures of active compounds ( $4 \mathrm{~m}$ and 4n) a flexible alignment was employed (Figure 5), using MOE/MMFF94, ${ }^{50}$ and 200 conformers of each compound were generated and minimized with a distance-dependant dielectric model. A low energy set of 100 was selected for further analysis. Conformations of compound (4m) were generated using distance geometry and optimized with MMFF94. Five low energy, maximally dissimilar structures were selected for comparison to the other compounds. After assigning MMFF94 charges to all molecules, flexible alignment was ranked overlays of compounds (4m and $4 n$ ) based on electrostatic, steric filed, hydrophobic areas overlap, hydrogen bond acceptors and donors overlap. From the highest scoring superposition, the limited set conformers was used in the analysis for molecules with high flexibility capable for achieving complete atom-to-atom superposition (Figure 5a). A common feature of the MOE-generated alignments showed, comply of the two structures (4m and $\mathbf{n})$ with: i) three phenyl rings (A, B and $\mathbf{C}$ ), ii) $\mathrm{COCH}_{2} \mathrm{NH}$ spacer between rings (Figure 5a). With the same way, antimicrobial of compound (4n) and the lowest active compounds (4d and $4 \mathbf{k}$ ) were subjected to flexible alignments. Analysis of weak active molecules (Figure 5b) is an important way to gain clear vision of the essential features for a given activity. It is clear that compounds (4d and $4 \mathbf{k}$ ) were flexibly aligned in a different manner when compared with the active compound 


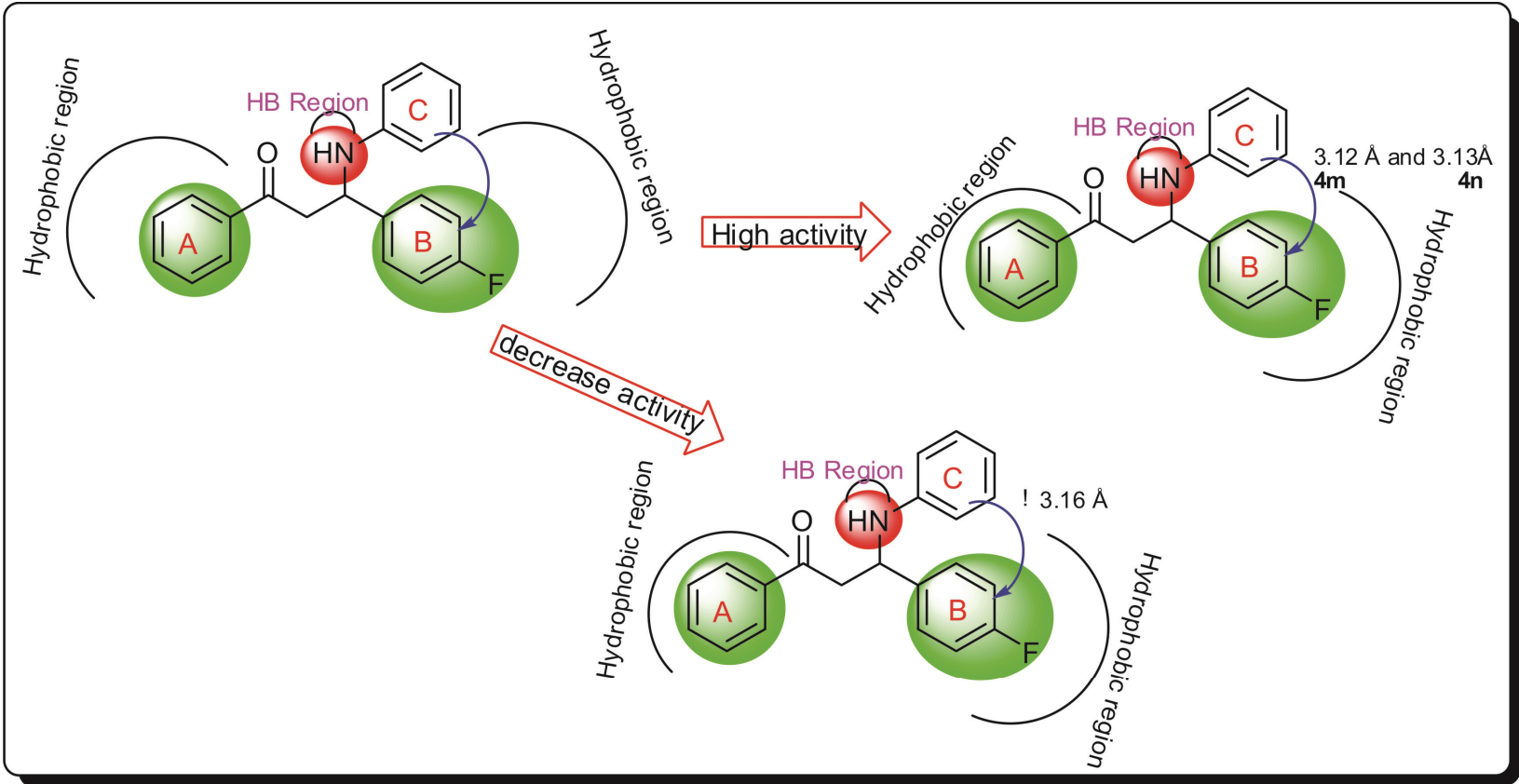

Figure 4. 2D-pharmacophoric design of $\beta$-amino ketone (red colors represent the HB regions, green colors represent hydrophobic regions and blue colors represent spacer moiety).

(4n). Common feature of the MOE-generated alignments showed, the superposition of the $\mathrm{COCH}_{2} \mathrm{NH}$ fragments in (4k) have a slight deviation $(0.5 \AA)$ compared with high active compound $(4 n)$, the three phenyl rings arrangement are in similar manner to all investigated compounds. These features explaining why such compound was the least active as antimicrobial agents and showing the importance of both $\mathrm{COCH}_{2} \mathrm{NH}$ moiety and the aromatic ring attached to it (Figure 5b).

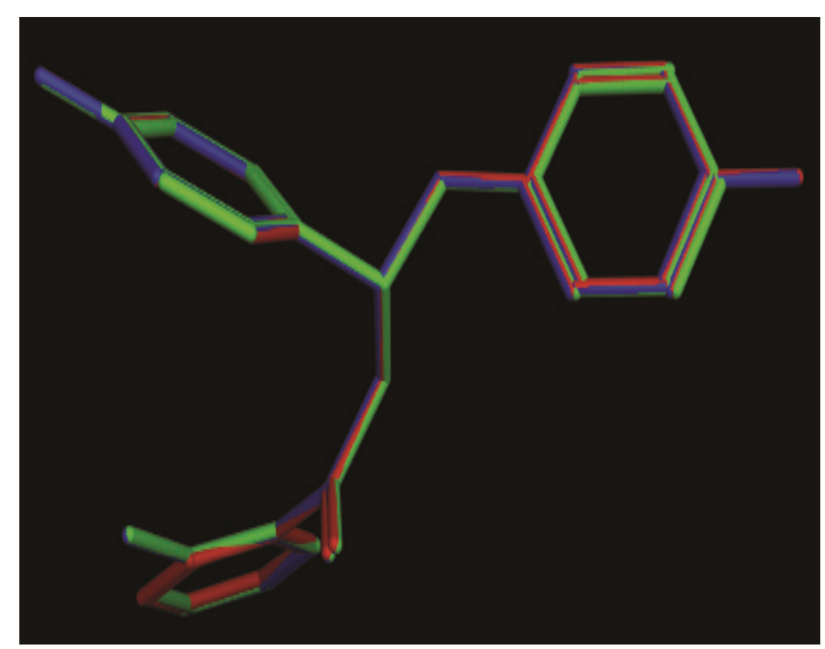

a

\section{Electrostatic and Hydrophobic Mappings}

In an attempt to understand the lowest activity represented by (4k) and the highest antimicrobial activity represented by (4n), electrostatic and hydrophobic mappings was preformed for the lowest energy conformers, to examine the comply and incompliance in electronic, electrostatic binding characteristics of the surface of the molecules and conformational properties (Figure 6). First: comparison of the electrostatic mappings of lowest active compounds, represented by compound (4k)

Figure 5. Flexible alignments of the most active compounds (Left panel): $\mathbf{4 d}$ (in green), $\mathbf{4 k}$ (in red) and $\mathbf{4 n}$ (in blue). Right panel showed flexible alignment of the high active compound $\mathbf{4 n}$ (in green) and lowest active compounds $\mathbf{4 d}$ (in red) and $\mathbf{4 k}$ (in blue). 


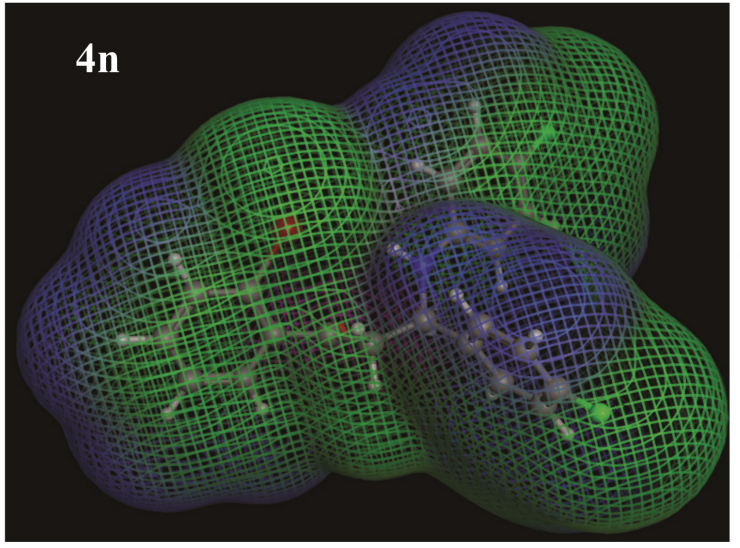

a

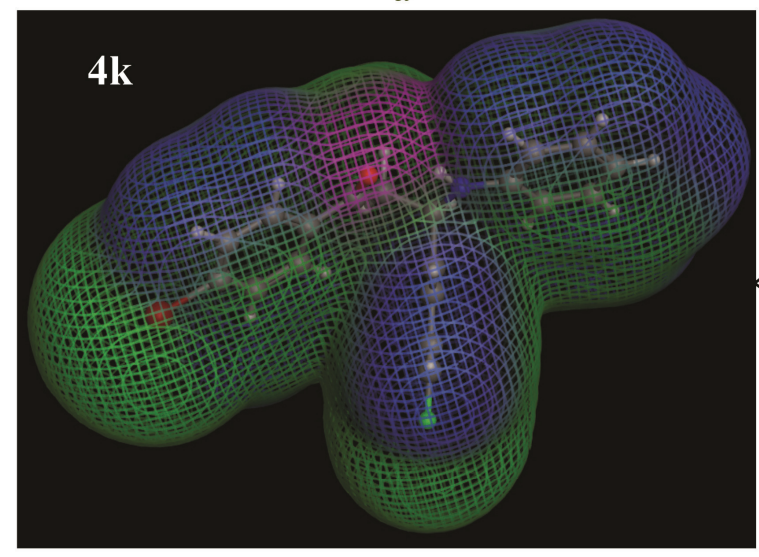

a

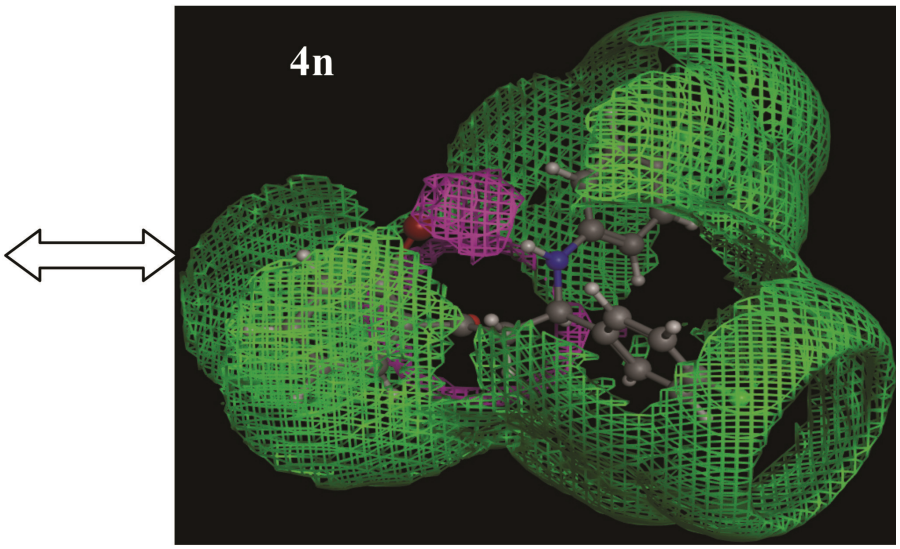

$\mathrm{b}$

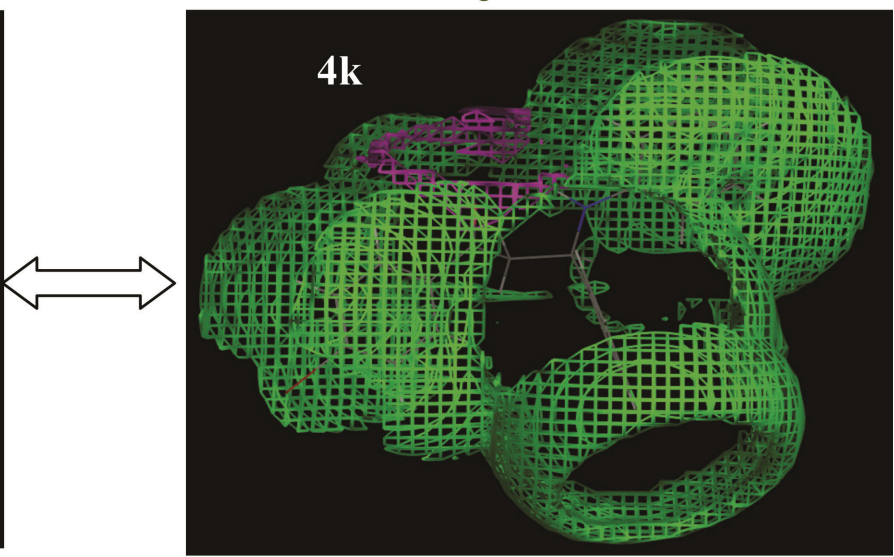

b

Figure 6. Electrostatic maps (left panels a) and hydrophobic panels (right panels b) of the lowest energy conformers for the most active compounds (4n) and the least active compounds (4k); maps are color coded: red for the hydrogen bond and a hydrophilic region, cyan for a medium polar region, and green for a hydrophobic region.

(Figure 6a) showed common features: i) negative charge located on the carbonyl (in red), ii) non-polar area located on the aryl moiety (in green), these features explain biological similarity among the low active analogues compounds. On the contrary, the high activity of compounds (4m and $n)$, represented by (4n, Figure 6) showed decrees distribution of negative charge (in red) on carbonyl group. From the above features, the low activity may be due to increasing negative charge located on the carbonyl group region representing hydrogen bond acceptor (in red) (Figure 6a). As the same analogy, hydrophobic mappings of the most active compound (4n) showed that, the hydrophobic region (in green) was distributed on all sides of aromatic rings (A, B and C) while the hydrophilic region (in red) was located mainly on carbonyl fragments (Figure 6b). On the other hand the hydrophobic distributions of the inactive compounds (4k) occupying aromatic ring, indicating dissimilarity hydrophobic distributions of such compound (Figure $6 b)$. It is clear that the related charge distribution, electrostatic and hydrophobic mappings suggest a similar interaction and orientations of the molecules with a potential protein-binding site.

\section{Pharmacophore Prediction}

The aim of this approach is generation and prediction a pharmacophore model (hypothesis) depending on the most active compound. These steps are employed for 3D pharmacophore applications: i) Compound 4n (Figure 4) used as reference to other conformations of each compounds. ii) Assignment of the pharmacophoric features. ii) Application method for undertaking conformational searching of databases for new structures matching to generated pharmacophoric features. These steps will be explained (hypothetical) pharmacophoric building of antimicrobial compounds. Molecular Operating Environment (MOE) programme was used for pharmacophore building. ${ }^{51}$ The calculated conformational models were preformed with $15 \mathrm{kcal}$ energy cut off (minimization convergence criteria during conformational analysis: energy convergence $=0.01 \mathrm{kcal} / \mathrm{mol}$, gradient convergence $=0.01 \mathrm{kcal} / \mathrm{mol}$ ). The number of conformers generated for each substrate was limited to a maximum of 500. All molecules with their associated 
Table 5. Pharmacophoric and structure features of the most active compounds

\begin{tabular}{ll}
\hline Pharmacophoric features & Structure features \\
\hline F1: Aro/Hydro & Pheny and $o$-bromophenyl \\
F2: Aro/Hydro & $p$-florophenyl \\
F3: Aro/Hydro & Pheny and $p$-florophenyl \\
F4: Acc & $\mathrm{C}=\mathrm{O}$ \\
F5: Don & $\mathrm{NH}$ \\
\hline
\end{tabular}

conformations were regrouped depending biological data. Hypothesis generation carried out with low energy conformers of the molecules. The calculation and analysis were preformed. After assignment of possible pharmacophore elements for each analogue using MOE program, then superposition of the molecules including the assigned elements, was attempted (Figure 7), to generate Pharmacophore maps, many runs of calculation were repeated. For each run, a distinct number of specified pharmacophore elements were generated. All appropriate models showed that, the donor atoms of the
NH fragments (as hydrophilic) element and the aryl moieties (as hydrophobic) were well superimposed within the set distance tolerance, which confirms the important role of the hydrophilic and hydrophobic moieties for antimicrobial activity. The initial pharmacophore query was carried out, and introducing of 5 features, as summarized in (Table 5) and illustrated graphically in (Figure 7).

From (Figure 7a), Models for (4n) and its analogs (4m) possess pharmacophore elements in the aromatic (ring C) attached to $\mathrm{NH}$ group (as a hydrogen bond donor) which is out of plane with aromatic ring (B), which parallel with aromatic ring (A). In contrast, model for (4d) and its analogs (4k) (Figure 7b) showed common elements, the aromatic ring (B) coplanar with aromatic ring (A), and aryl amino part out of plane with aromatic ring (A) (Figure 7b). Since the arylamino- part of compound (4n) plays an important role in activity. According to the pharmacophore generated by $\mathrm{MOE}^{51}$ the minimal structural requirements for antimicrobial activity consist of an aromatic ring (hydrophobic re-

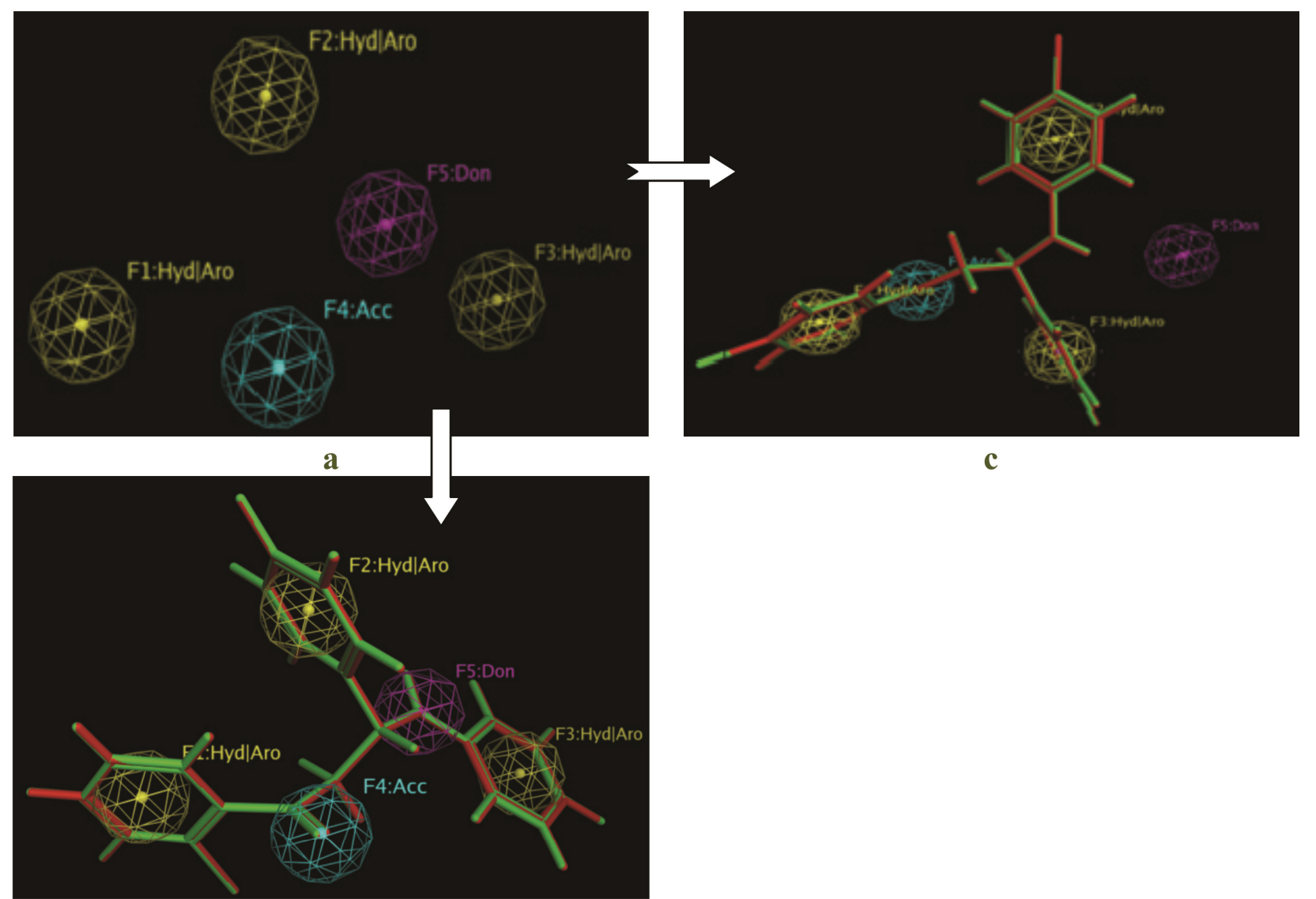

b

Figure 7. a) Showed the best predicted pharmacophore features and geometries which are required for antimicrobial activity. b) Showed the most active compounds $\mathbf{4 m}$ and $\mathbf{4 n}$ mapped to the pharmacophore model for antibicrobial activity. c) Showed the lowest active compounds (4d and $\mathbf{4 k}$ ) mapped to the pharmacophore model for antimicrobial activity. Pharmacophore features are color coded: yellow for hydrophobic aromatics, cyane for a hydrogen bond donor, and blue for a hydrogen bond acceptor feature. 
gion) attached to $\mathrm{NH}$ fragment (H-bonding donor region), and carbonyl fragment (H-bonding acceptor region) (Figures 4 and 7). This pharmacophoric assumption was in consistence with biological data.

\section{CONCLUSIONS}

A facile and efficient one-pot three-component reaction between $p$-fluorobezaldehyde, selected acetophenone and several aniline derivatives, catalyzed by silica sulfuric acid (SSA) for the synthesis of new $\beta$-amino carbonyl compounds (4) was investigated via Mannich reaction to yield products (4) in good to excellent yields and in short time. Flexible alignment was conducted and justified the importance of the main molecular groups (particularly, the carbonyl fragment and the aryl rings (A and $\mathbf{C}$ ) as well as of their relative distance. In fact, the substitution patterns on the phenyl ring (A or $\mathbf{C}$ ) considerably affect the activity. The overall outcome of this model revealed that: i) the phenyl rings (A, B and C) are a satisfactory backbone for antimicrobial activity, (ii) the aryl (ring A) should be about less than $3.16 \AA$ apart from the (ring C) (Figure 2). iii) Absence of bromine as hydrophobic moiety at position 6 decreased the activity, such as 4-(fluoro, chloro and methyl) phenyl moiety, this indicted the importance of position 6 in the activity. These modeling studies could be very useful for the virtual screening in the development of the presently studied $\beta$-amino carbonyl compounds as antimicrobial agents. Therefore, the present work led to the development of novel antimicrobial agents especially in case of the two novel molecules (4m and $4 \mathrm{n}$ ) for their noticed higher activity than all the other tested compounds.

\section{REFERENCES}

1. (a) B. E. Smart, J. Fluorine Chem. 109 (2001) 3-11; (b) J. Scheirs, Modern Fluoropolymers: High Performance Polymers for diverse applications, John Wiley and Sons, New York, 1997; (c) B. K. Park, N. R. Kitteringham, and P. M. O'Neill, Annu. Rev. Pharmacol. Toxicol. 41 (2001) 443-470; (d) J. T. Welch and S. Eswarakrishnan, Fluorine in Bioorganic Chemistry, John Wiley and Sons, Chichester, 1991.

2. J. M. Percy, Building Blocks Approaches to Aliphatic Organofluorine (Techniques and Synthons), Springer, BerlinHeidelberg, 1997, Vol. 193, pp. 131-195.

3. W. Hua, P. Wangb, C. Song, Z. Pan, Q. Wang, X. Guo, X. Yu, Z. Shen, S. Wang, and J. Chang, Bioorg. Med. Chem. Lett. 20 (2010) 7297-7298.

4. (a) M. Arend, B. Westermann, and N. Risch, Angew. Chem. Int. Ed. 37 (1998) 1044-1070; (b) C. Mannich and W. Krosche, Arch. der Pharm 250 (1912) 647-667; (c) F. C. Mukhopadhyay, S. Rana, and R. J. Butcher, Tetrahedron Lett. 52 (2011) 4153-4157.

5. R. Müller, H. Goesmann, and H. Waldmann, Angew. Chem./Angew. Chem. Int. Ed. 111 (38) (1999) 166-169/ 184-187.
6. (a) B. M. Trost and L. R. Terrell, J. Am. Chem. Soc. 125 (2003) 338-339; (b) S. Matsunaga, N. Kumagai, S. Harada, and M. Shibasaki, J. Am. Chem. Soc. 125 (2003) 4712-4713; (c) K. Juhl, N. Gathergood, and K. Jørgensen, Angew.Chem. 113 (2001) 3083-3085; (d) B. List, J. Am Chem. Soc. 122 (2000) 9336-9337; (e) B. List, P. Pojarliev, W. T. Biller, and H. J. Martin, J. Am. Chem. Soc. 124 (2002) 827-833; (f) A. Cordova, W. Notz, G. Zhong and J. M. Betancort, J. Am. Chem. Soc. 124 (2002) 184z1843; (g) S. Kobayashi, T. Hamada a nd K. Manabe, J. Am. Chem. Soc. 124 (2002) 56405641; (h) Y. Hayashi, W. Tsuboi, I. Ashimine, T. Urushima, M. Shoji, and K. Sakai, Angew. Chem. Int. Ed. 43 (2003) 3677-3680; (i) A. G. Wenzel and E. N. Jacobsen, J. Am. Chem. Soc. 124 (2002) 12964-12965.

7. (a) M. M. Salter, J. Kobayashi, and S. Kobayashi, Org. Lett. 8 (2006) 3533-3536; (b) S. Kikuchi, T. Kobayashi, and Y. Hashimoto, Tetrahedron Lett. 47 (2006) 1973-1975; (c) J. Kobayashi, Y. Yamashita, and S. Kobayashi, Chem. Lett. 34 (2005) 268-269; (d) W. G. Shou, Y. Y. Yang and Y. G. Wang, Tetrahedron Lett. 47 (2006) 1845-1847; (e) R. Wang, B-g. Li, T-k. Huang, L. Shi and X-x. Lu, Tetrahedron Lett. 48 (2007) 2071-2073.

8. T. Akiyama, K. Matsuda, and K. Fuchibe, Synlett 2 (2005) 322-324.

9. K. Matsuda, Y. Mori, and S. Kobayashi, Tetrahedron 57 (2001) 2537-2544.

10. T. Akiyama, J. Takaya, and H. Kagoshima, Synlett 7 (1999) 1045-1048.

11. S. Iimura, D. Nobutou, K. Manabe, and S. Kobayashi, Chem. Commun. (2003) 1644-1645.

12. T. Akiyama, J. Itoh, K. Yokota, and K. Fuchibe, Angew. Chem. Int. Ed. 43 (2004) 1566-1568.

13. A. Hasegawa, Y. Naganawa, M. Fushimi, K. Ishihara, and H. Yamamoto, Org. Lett. 8 (2006) 3175-3178.

14. M. A. Zolfigol, Tetrahedron 57 (2001) 9509-9511.

15. P. Salehi, M. A. Zolfigol, F. Shirini, and M. Baghbanzadeh, Curr. Org. Chem. 10 (2006) 2171-2189.

16. B. F. Mirjalili, M. A. Zolfigol, A. Bamoniri, and A. Hazar, Bull Korean Chem. Soc. 25 (2004) 865-868.

17. K. Shimizu, E. Hayashi, T. Hatamachi, T. Kodama, and Y. Kitayama, Tetrahedron Lett. 45 (2004) 5135-5138.

18. A. Shaabani and A. Rahmati, J. Mol. Catal. A. Chem. 249 (2006) 246-248.

19. P. Salehi, M. Dabiri, M. A. Zolfigol, and M. A. Badaghifard, Phosphorus, Sulfur, Silicon Relat. Elem. 179 (2004) 1113-1121.

20. U. V. Desai, T. S. Thopate, D. M. Pore, and P.P. Wadgaonkar, Cat. Commun. 7 (2006) 508-511.

21. B. Mukhopadhyay, Tetrahedron Lett. 47 (2006) 4337-4341.

22. F. Kazemi, A. R. Massah, F. Kazemi, D. Azadi, S. Farzaneh, H. Aliyan, N. H. Javaherian, and A. R. Momeni, Lett.Org. Chem. 3 (2006) 235-241.

23. V. Ajayan; H. Kazi Zakir, and A. Katsuhiko, J. Nanosci. Nanotechnol. 5 (3) (2005) 347-371.

24. G. Oye, J. Sjoblom, and M. Stocker, Adv. Colloid Interface Sci. 89-90 (2001) 439-466.

25. A. Corma, Chem. Rev. 97 (1997) 2373-2419.

26. N. G. Kozlov and L. I. Basalaeva, Russ. J. General. Chem. 74 (2004) 926-932; Translated from Zhurnal Obshchei Khimii, 74 (6) (2004) 1003-1008.

27. I. Koslow, J. Gen. Chem.USSR. 35 (1965) 285-286.

28. V. Kanagarajan, J. Thanusu and M. Gopalakrishnan, Eur. J. Med. Chem. 45 (2010) 1583-1589.

29. (a) M. Saroj, P. Kalpna, R. Brij, and C.G. Komal, J. Chem. \& Eng. Data. 28 (1983) 430-431; (b) B. P. John, C. D. Stephen, D. C.Daniel, H. R. Brian, P. J. Elizabeth, and R. M. Theresa; Astrazeneca AB; Astrazeneca UK Ltd. Patent:WO2004/ 11410 (A1), 2004; EP1549600 A1; JP2005/533858 A 
30. P. C. Lv, D. D. Li, Q. S. Li, X. Lu, Z. P. Xiao, and H. L. Zhu, Bioorg. Med. Chem. Lett. 21 (2011) 5374-5377.

31. P. Ask, R. H. Christian, F. Andre, C. Allesia, and K. Jan, Synthesis 2 (2005) 291-295.

32. N. G. Kozlov and L. I. Basalaeva, Russ. J. General. Chem. 74 (2004) 926-932; Translated from Zhurnal Obshchei Khimii, 74 (6) (2004) 1003-1008.

33. I. Koslow, J. Gen. Chem.USSR. 35 (1965) 285-286.

34. Manual of Molecular Operating Environment (MOE) Version 2007.09 Chemical Computing Group Inc., Montreal, Quebec, Canada, 2007.

35. D. S. Badawy, E. Abdel-Galil, E. M. Kandeel, W. M. Basyouni, Kh. A. M. El-Bayouki, and T. K. Khatab, Phosphorus, Sulfur and Silicon 184 (2009) 220-233.

36. D. S. Badawy, E. Abdel-Galil, E. M. Kandeel, W. M. Basyouni, and T. K. Khatab, Phosphorus, Sulfur and Silicon 148 (2009) 2799-2812.

37. T. K. Khatab, Kh. A. M. El-Bayouki, and W. M. Basyouni, Tetrahedron Lett. 52 (2011) 1448-1451.

38. B. R. Kumar, M. D. Karvekar, L. Adhikary, M. J. Nanjan, and B. J. Suresh, Het. Chem. 43 (2006) 897-903.

39. Y. Xiaoliang, Xu. Yali, C. Jiuxi, D. Jinchang, Wu. Huayue, and Su. Weike, J. Chem. Res. 11 (Synopses) (2009) 682-685.

40. E. Jawetz, J. Melnick, and E. Adelberg, Lang Medical Publica- tion, Los Altos, California, $25^{\text {th }}$ Edition, Publisher: Mc/w HMed, 2110, ISBN: 0071624961, p. 832.

41. J. Grayer and J. Harbone, Phytochemistry 37 (1994) 19-42.

42. D. Muanza, B. Kim, K. Euler, and L. Williams, Pharm. Biol. 32 (1994) 337-345.

43. O. Irobi, M. Moo-Young, and W. Anderson, Pharm. Biol. 34 (1996) 87-90.

44. S. H. Gillespie, Medical Microbiology-Illustrated., Butterworth Heinemann Ltd., United Kingdom, 234-247, 1994.

45. C. A. Lipinski, F. Lombardo, B. W. Dominy, and P. J. Feeney, Adv. Drug. Delivery Rev. 23 (1997) 3-25.

46. D. E. Clark and S. D. Pickett, Drug Discov. Today 5 (2000) 49-58.

47. Software: Chemical Computing Group Mode 2009.10 Multiplatform $h t t p: / / w w w$. downarchive.com/software/

48. S. A.Wildman and G. M. Crippen, J. Chem. Inf. Comput. Sci. 39 (1999) 868-873.

49. S. Profeta and N. L. Allinger, J. Am. Chem. Soc. 107 (1985) 1907-1918.

50. (a) T. A. Halgren, J. Comput. Chem. 17 (1996) 490-519; (b) H. Liu, C. R. McCurdy, and R. J. Doerksen, Theochem 945 (2010) $57-63$.

51. M. J. S. Dewar, E. G. Zoebisch, E. F. Healy, and J. J. P. Stewart, J. Am. Chem. Soc. 107 (1985) 3902-3909. 